\title{
6-Substituted 2-oxo-2H-1-benzopyran-3-carboxylic acid derivatives in a new approach of the treatment of cancer cell invasion and metastasis
}

\author{
Isabelle Kempen ${ }^{a}$, Marc Hemmer ${ }^{a}$, Stéphane Counerotte ${ }^{a}$, Lionel Pochet ${ }^{b}$, Pascal de Tullio ${ }^{\text {a }}$, Jean-Michel \\ Foidart $^{c}$, Silvia Blacher ${ }^{c}$, Agnès Noël ${ }^{c}$, Francis Frankenne ${ }^{c}$, Bernard Pirotte ${ }^{a}$ \\ ${ }^{a}$ Drug Research Center, Laboratoire de Chimie Pharmaceutique, Université de Liège, 1 Avenue de l'Hôpital, tour 4 (+5), Sart-Tilman, B- \\ 4000 Liège, Belgium \\ ${ }^{\mathrm{b}}$ Département de Pharmacie, Université de Namur, FUNDP, 61 rue de Bruxelles, B-5000 Namur, Belgium \\ ${ }^{\mathrm{c}}$ Laboratoire de Biologie des Tumeurs et du Développement, Université de Liège, 1 Avenue de l'Hôpital, tour 3 (+4), Sart-Tilman, B-4000 \\ Liège, Belgium
}

\begin{abstract}
Novel 6-substituted 2-oxo-2H-1-benzopyran-3-carboxylic acid derivatives were synthesized and their potency in reducing the invasive behaviour of HT 1080 fibrosarcoma cells was evaluated. Structure-activity relationships were deduced from biological results and will be used in further design of new active compounds. In particular, the acetoxymethyl substituent found at the 6-position of previously described active compounds can be replaced by an acetamidomethyl substituent without loss of potency; while the presence of an aryl ester function at the 3position was preferred to a thioester or an amide function to induce marked biological activity.
\end{abstract}

This work confirms the interest of aryl esters of 6-substituted coumarin-3-carboxylic acids as potential new anticancer agents.

Keywords: coumarin derivatives; cancer; cell invasion; anti-cancer drug

\section{Introduction}

One of the most difficult problems arising during cancer therapy is the occurrence of cancer cell invasion responsible for the spread of tumour cells throughout the body. Such an event leading to metastases is an important cause of the bad prognosis of numerous cancers. Although anti-cancer chemotherapy mainly consists in the use of cytotoxic agents interfering with cell division, another research field has recently emerged with the design and identification of agents able to inhibit or limit the metastatic process. Indeed, many efforts are now focussed on the search of compounds interfering with the cancer cell invasion process and expressing antiangiogenic properties [1]. Examples of drugs, among which monoclonal antibodies and small molecules, are currently under clinical investigation and some of them have recently been approved for use in man in the treatment of several cancers associated or not with conventional chemotherapies or radiation therapies [2-9]. These drugs comprise vascular endothelial growth factor (VEGF) and epidermal growth factor (EGF) inhibitors (monoclonal antibodies) as well as VEGF and EGF receptor tyrosine kinase inhibitors (small-molecule inhibitors), but also matrix metalloproteinase (MMP), urokinase (uPA), cycloogygenase-2 (COX-2) or methionine aminopeptidase inhibitors [1].

We recently reported that two synthetic 6-substituted coumarin-3-carboxylic acid derivatives, 3chlorophenyl 6-acetoxymethyl-2-oxo-2 $H$-1-benzopyran-3-carboxylate (1) and 3-bromophenyl 6-acetoxymethyl2-oxo-2H-1-benzopyran-3-carboxylate (2) (Fig. 1), expressed a marked potency in inhibiting cancer cell invasion in vitro and tumour growth in vivo [10]. Simple natural and synthetic coumarins such as esculetin (3), osthole (4) and the synthetic 6-nitro-substituted coumarin (5) (Fig. 1) are also known for a long time to exert anti-cancer properties, but, for most of them, by an unknown mechanism [11-14]. Recently reported coumarin derivatives such as G8935 (6) (Fig. 1), structurally related to 1 and 2 and identified as mitogen activated protein (MAP) kinase/extracellular signal-regulated kinase (ERK) kinase inhibitors (MEK1 inhibitors), raise the possibility that the coumarin-3-carboxylates 1 and $\mathbf{2}$ may exert their anti-cancer activity through inhibition of MEK1 [15]. Another recent work showed that coumarin-3-carboxamides (7, Fig. 1) tightly related to the chemical structure of 1 and 2 selectively inhibited the tumour cells that have a high level of epidermal growth factor receptor (EGRF or erbB1) and erbB2 (HER2) receptor expression [16].

Interestingly, the chemical structure of the active coumarins 1 and $\mathbf{2}$ may be compared to that of linomide (roquinimex) (8, Fig. 2), a quinolinone isostere of coumarins known to be an immunomodulator, but also expressing anti-angiogenic activity in vitro and in vivo [17-19]. Moreover, the preferred conformation adopted by linomide, as found in the crystal [20] (8'; Fig. 2), can be superimposed to the preferential conformation adopted, in the solid state and probably in solution, by aryl esters of coumarin-3-carboxylic acid derivatives (9'; Fig. 2) in accordance to recent published crystallographic and molecular modelling studies [21,22]. In contrast to 
aryl esters of 6-substituted coumarin-3-carboxylic acids, the corresponding aryl amides $\mathbf{1 0}$ (Fig. 2) are not able to adopt such conformation because a strong intra-molecular hydrogen bound is established between the hydrogen atom of the exocyclic NH group and the lactonic carbonyl group [21].

Using coumarins 1 and 2 as lead compounds, the present work aimed at describing new examples of coumarin-3carboxylic acid derivatives in order to better define structure-activity relationships that could explain their antiinvasive activity. Particular attention was paid to the replacement of the oxygen atom included in the exocyclic ester function in the 3-position by a sulphur atom (thioesters) or by a nitrogen atom (amides) with or without a methyl group. The importance of the nature and the size of the substituent in the 6-position was also examined. Among them, the replacement of the metabolically labile ester function (acetoxymethyl moiety) in the 6-position by a more stable amide function (acetamidomethyl moiety) was investigated. In these series, the presence of a halogen atom in the meta position of the phenyl ring in the 3 -position (preferably a chlorine or a bromine atom) was maintained like in the structure of the lead compounds 1 and 2.

Fig. 1. Chemical structure of coumarins known to exert anti-cancer activity.<smiles>[X]c1cccc(OC(=O)c2cc3cc(COC(C)=O)ccc3oc2=O)c1</smiles>

1: $\mathrm{X}=\mathrm{Cl}$

2: $\mathrm{X}=\mathrm{Br}$<smiles>COc1ccc2ccc(=O)oc2c1CC=C(C)C</smiles><smiles>CN(C)C(=O)Oc1ccc2cc(Cc3ccc(F)cc3)c(=O)oc2c1</smiles><smiles>O=c1ccc2cc(O)c(O)cc2o1</smiles>

3<smiles>O=c1ccc2cc([N+](=O)[O-])c(O)cc2o1</smiles>

5<smiles>[X]c1ccccc1NC(=O)c1cc2ccccc2oc1=O</smiles>

7 
Fig. 2. Structure of the anti-angiogenic drug linomide (8) in two different conformations. The 'cis' conformation of linomide (8') can be superimposed to the low energy 'cis' conformation of the coumarinic aryl esters (9') but not to the stable conformation of the coumarinic aryl amides (10) characterised by the existence of a strong intra-molecular hydrogen bond.<smiles>CN(C(=O)c1c(O)c2ccccc2n(C)c1=O)c1ccccc1</smiles>

8<smiles>[X]c1cccc(OC(=O)c2cc3cc([X])ccc3oc2=O)c1</smiles><smiles>CN(C(=O)c1c(O)c2ccccc2n(C)c1=O)c1ccccc1</smiles>

8'<smiles>[X]c1ccc2oc(=O)c(C(=O)Oc3ccccc3)cc2c1</smiles>

9

$9^{\prime}$<smiles></smiles>

10

\section{Chemistry}

Scheme 1 illustrates the synthetic pathway giving access to the coumarinic derivatives characterised by the introduction of a thioester function or an amide function in the 3-position.

Compound 12 obtained from 11 by acetylation was converted into the corresponding acid chloride $\mathbf{1 3}$ as previously described [21,23]. The acyl chloride intermediate $\mathbf{1 3}$ then reacted with appropriate thiophenols and anilines to provide the thioesters 14, the secondary amides 15 and the tertiary amides 16 (Scheme 1).

Starting from 11, acylation, with the appropriate anhydride, of the exocyclic $\mathrm{OH}$ function located on the hydroxymethyl group in the 6-position led to the acid esters $\mathbf{1 7}$ (Scheme 2). The latter intermediates were converted into the acyl chlorides 18 and then into the 3-bromophenyl esters 19 after reaction of 18 with 3bromophenol in the presence of a base (Scheme 2).

Examples of coumarin derivatives with a nitro group in the 6-position were obtained according to Scheme 3 . The commercially available 5-nitrosalicylaldehyde $\mathbf{2 0}$ was converted into ethyl 6-nitrocoumarin-3-carboxylate $\mathbf{2 1}$ after reaction with ethyl malonate in the 'Knoevenaegel' reaction conditions. The ethyl ester 21 was hydrolyzed to provide the corresponding carboxylic acid 22. The latter was converted into the acyl chloride 23 which then reacted with the appropriate metahalophenol to provide the aryl esters 24.

Finally, 6-aminomethyl- (27) and 6-acetamidomethyl-substituted (28) halophenyl esters of coumarin-3carboxylic acid were obtained according to Scheme 4. Compounds 25 previously described [23] reacted with hexamethylenetetramine to give the hexaminium salts 26. The 'Delepine' reaction conditions of hydrolysis were then used to convert the hexaminium salts into the corresponding primary amines 27. In the last step, acetylation of the amine function of $\mathbf{2 7}$ provided the corresponding acetamides $\mathbf{2 8}$. 
Scheme 1. Reagents: (i) $\mathrm{Ac}_{2} \mathrm{O}$; (ii) $\mathrm{SOCl}_{2}$; (iii) $\mathrm{ArSH}$, pyridine, dioxane; (iv) $\mathrm{ArNH}_{2}$, pyridine, dioxane; and (v) ArNHCH , pyridine, dioxane.<smiles>CC(C)CCCCCO</smiles>

11<smiles>CC(=O)OCc1ccc2oc(=O)c(C(=O)O)cc2c1</smiles>

12

ii<smiles>[X]c1cccc(SC(=O)c2cc3cc(COC(C)=O)ccc3oc2=O)c1</smiles>

14 14a: $X=H$

14b: $X=C l$

14c: $X=B r$

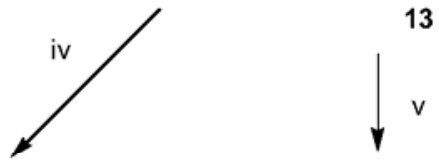<smiles>[X]c1cccc(NC(=O)c2cc3cc(COC(C)=O)ccc3oc2=O)c1</smiles>

$1515 a: X=C l$<smiles>[X]c1ccccc1N(C)C(=O)c1cc2cc(COC(C)=O)ccc2oc1=O</smiles>

$1616 \mathrm{a}: \mathrm{X}=2-\mathrm{Cl}$

16b: $X=3-\mathrm{Cl}$

16c: $X=4-\mathrm{Cl}$

Scheme 2. Reagents: (i) (RCO) ${ }_{2} \mathrm{O}$; (ii) $\mathrm{SOCl}_{2}$; and (iii) 3-bromophenol, pyridine, dioxane.<smiles>O=C(O)c1cc2cc(CO)ccc2oc1=O</smiles><smiles>[R]C(=O)OCc1ccc2oc(=O)c(C(=O)O)cc2c1</smiles><smiles>[R]C(=O)OCc1ccc2oc(=O)c(C(=O)Cl)cc2c1</smiles>

17a, 18a, 19a: $\mathrm{R}=-\mathrm{CH}_{2} \mathrm{CH}_{3}$ 17b, 18b, 19b: $\mathrm{R}=-\left(\mathrm{CH}_{2}\right)_{2} \mathrm{CH}_{3}$

17c, 18c, 19c: $\mathrm{R}=-\left(\mathrm{CH}_{2}\right)_{3} \mathrm{CH}_{3}$

$17 \mathrm{~d}, 18 \mathrm{~d}, 19 \mathrm{~d}: \mathrm{R}=-\left(\mathrm{CH}_{2}\right)_{4} \mathrm{CH}_{3}$

$17 \mathrm{e}, 18 \mathrm{e}, 19 \mathrm{e}: \mathrm{R}=-\left(\mathrm{CH}_{2}\right)_{5} \mathrm{CH}_{3}$

17f, 18f, 19f: $\mathrm{R}=-\mathrm{CH}\left(\mathrm{CH}_{3}\right)_{2}$

17g, 18g, 19g: $\mathrm{R}=-\mathrm{C}\left(\mathrm{CH}_{3}\right)_{3}$ 
Scheme 3. Reagents: (i) diethyl malonate, piperidine, $\mathrm{HOAc}$, EtOH; (ii) $\mathrm{NaOH}, \mathrm{H}_{2} \mathrm{O}$; (iii) $\mathrm{SOCl}_{2}$; and (iv) 3halophenol, pyridine, dioxane.<smiles>CCCCCC=O</smiles>

20<smiles>O=C(Cl)c1cc2cc([N+](=O)[O-])ccc2oc1=O</smiles>

23<smiles>CCOC(=O)c1cc2cc([N+](=O)[O-])ccc2oc1=O</smiles>

21<smiles>COc1ccc2oc(=O)c(C(=O)O)cc2c1</smiles>

22

24a: $X=H$

24b: $X=F$

24c: $X=\mathrm{Cl}$

24d: $X=B r$

24e: $X=1$<smiles>[X]c1cccc(OC(=O)c2cc3cc([N+](=O)[O-])ccc3oc2=O)c1</smiles>

Scheme 4. Reagents: (i) hexamethylenetetramine, $\mathrm{CHCl}_{3}$; (ii) $\mathrm{HCl}, \mathrm{EtOH}$; and (iii) $\mathrm{Ac}{ }_{2} \mathrm{O}, \mathrm{TEA}, \mathrm{DMF}$.<smiles>[X]c1cccc(OC(=O)c2cc3cc(CCl)ccc3oc2=O)c1</smiles>

25<smiles></smiles>

26

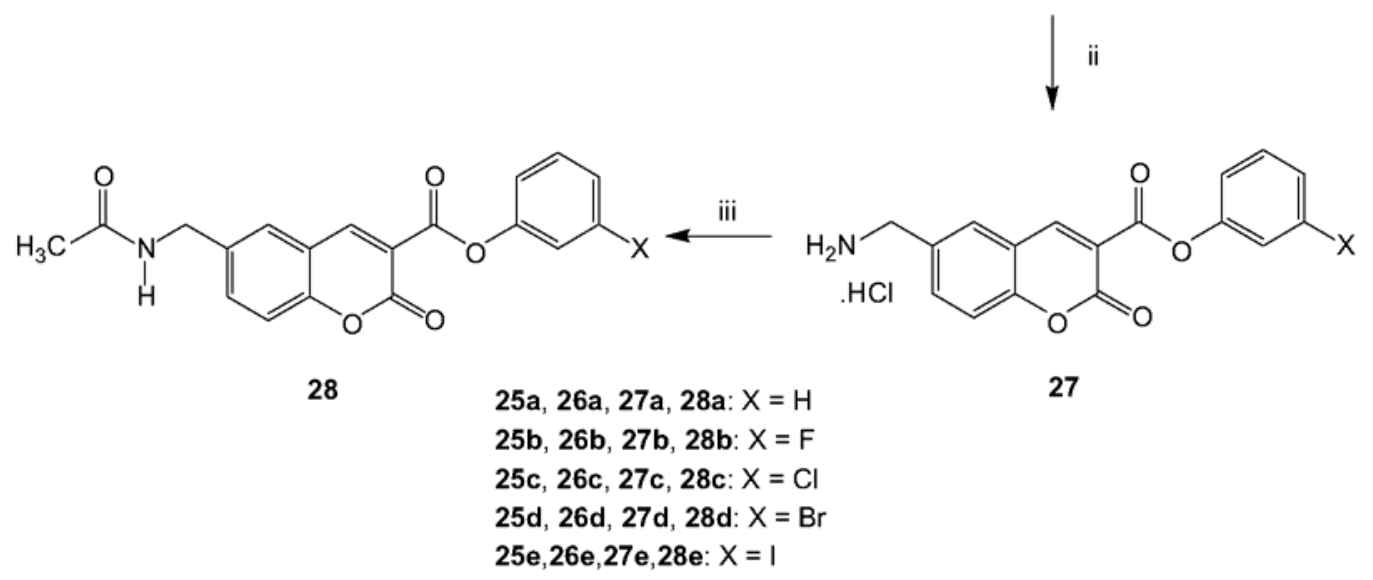

\section{Results and discussion}

The new synthetic coumarins were examined in a 'Boyden chamber' invasion assay using HT 1080 fibrosarcoma cells in order to determine their potency in reducing the invasive behaviour of tumour cells [10]. The assay consists in measuring the ability of cells treated or not with the coumarinic derivatives tested at different concentrations to pass through type IV collagen-coated Transwell cell culture inserts (chemoinvasion assay). Cell invasion in the absence of coumarin derivative was considered as $100 \%$. Results were compared to those 
observed with a reference compound, GI 129471 (29, Fig. 3), a well-known broad-spectrum hydroxamate-type MMP inhibitor, used at $1 \mu \mathrm{M}$ concentration, previously reported to be active in this model [10], and also compared to those obtained with the active coumarin derivatives $\mathbf{1}$ and $\mathbf{2}$ at three different concentrations: $0.1,1$ and $10 \mu \mathrm{M}$. The activity at $1 \mu \mathrm{M}$ of another synthetic MMP inhibitor, Ro 28-2653 (30, Fig. 3), an MMP2/MMP-9/MT-MMP-selective inhibitor, was also examined in the same chemoinvasion assay.

Fig. 3. Chemical structure of two synthetic MMP inhibitors.<smiles>CC(C)CC(C(=O)NO)C(CSc1ccccc1)C(=O)N(C)C(Cc1ccccc1)C(=O)O</smiles>

GI $129471(29)$

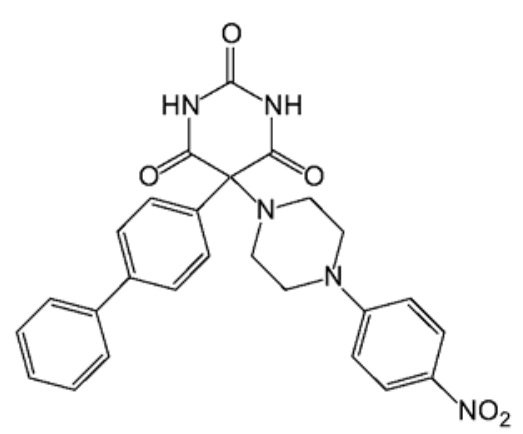

Ro28-2653 (30)

Table 1 indicates that GI 129471 at $1 \mu \mathrm{M}$ concentration was able to reduce by $62 \%$ the invasion of HT 1080 cells through type IV collagen. The other MMP inhibitor, Ro 28-2653, was found to be equally active to GI 129471 at $1 \mu \mathrm{M}$. As previously reported, the bromo-substituted coumarin 2 giving $78 \%$ inhibition of cell invasion at $1 \mu \mathrm{M}$ concentration was found to be more potent than the reference compound GI 129471, whereas the corresponding chloro-substituted analogue 1 was also active (51\% inhibition of cell invasion at $1 \mu \mathrm{M})$ but less potent than the two formers [10].

Replacement of the oxygen atom of the exocyclic ester function in the 3-position by a sulphur atom (thioesters 14a-c) resulted in a significant reduction of the ability of the drugs at inhibiting HT 1080 cell invasion through type IV collagen (compare the results obtained with 14b versus 1 and with 14c versus 2 at 1 and $10 \mu \mathrm{M}$ ). The absence of a halogen atom on the phenyl ring (see 14a) appeared to be unfavourable for the anti-invasive activity compared to halo-substituted compounds.

The secondary amide 15a, resulting from the replacement of the oxygen atom of the exocyclic ester function of compound 1 by a NH group, was also found to be less active than 1 giving 33\% inhibition of cell invasion at 1 $\mu \mathrm{M}$ (versus $51 \%$ for 1 ) and $57 \%$ inhibition at $10 \mu \mathrm{M}$ (versus $94 \%$ for 1 ). Such an effect could be explained by the fact that amides such as 15a may adopt a stable conformation in which a strong hydrogen bond interaction is established between the NH group and the lactonic carbonyl oxygen. By contrast, a greater conformational freedom is given to esters such as $\mathbf{1}$ and $\mathbf{2}$ which may adopt the putative favourable 'cis' conformation of the two carbonyl groups (see structure 9', Fig. 2).

Surprisingly, compound $\mathbf{1 6} \mathbf{b}$, the $N$-methyl derivative of 15a, was not very potent in the cell invasion assay, although the presence of a methyl group on the nitrogen atom warranted the absence of intra-molecular H-bond interaction with the lactonic carbonyl group.

Table 1 also reports examples of analogues of the lead compound 2 for which the size and the branching of the alkyl chain on the acyloxymethyl group in the 6-position were modified. An increase in the size of the chain conducted to a progressive reduction of drug efficacy in inhibiting cell invasion. Interestingly, the branching of the alkyl chain with $\mathbf{1 9 f}$ (isopropyl) and $\mathbf{1 9 g}$ (tert-butyl) led to a less pronounced decrease of their biological activity compared to compound 2. Marked differences can be seen especially at $0.1 \mu \mathrm{M}$ between the linear (19a19e) and the branched (19f-19g) 6-acyloxymethylcoumarin derivatives.

The replacement of the acetyloxymethyl substituent in the 6-position of the coumarin ring of compound 1 or compound 2 by another substituent such as a nitro, an aminomethyl and an acetamidomethyl moiety was also examined. The biological results obtained in the 'Boyden chamber' assay with the compounds are reported in Table 2. The efficacy of the new coumarin derivatives in this test was compared to that of previously reported coumarins bearing a hydrogen atom (31), a methyl (32), a chloromethyl (25c) and an acetoxymethyl group (1 and 2) in the 6-position [10].

Compared to 2 , the replacement of the acetoxymethyl moiety in the 6-position by a nitro group gave rise to a less potent bromophenyl ester 24d when tested at $1 \mu \mathrm{M}$ in the chemoinvasion assay, but the latter was the most potent compound among the 6-nitro-substituted coumarins (24a-e) indicating that the presence of a bromine 
atom on the phenyl ring was the best choice of halogen atom in this series of coumarinic compounds.

In the case of the 6-aminomethyl-substituted coumarins (27a-e), the bromophenyl ester 27d was less potent than the corresponding bromophenyl reference compound 2. Interestingly, the best choice of halogen atom on the phenyl ring was the most bulky and lipophilic iodine atom giving rise to the very potent compound 27e. Thus, except in the case of an iodine atom, another halogen atom on the phenyl ring didn't improve the activity.

When the amino group is acetylated, the resulting compounds (28a-e) are the amide isosteres of compounds 1 and 2. The iodophenyl ester $\mathbf{2 8 e}$ was found to be as potent as the reference compound $\mathbf{2}$ at a $1 \mu \mathrm{M}$ concentration. The chloro-substituted amide compound 28c expressed a better activity at $1 \mu \mathrm{M}$ than its corresponding ester isostere $\mathbf{1}$ in the chemoinvasion assay, while the bromo-substituted amide $\mathbf{2 8 d}$ was found to be slightly less potent than its ester analogue 2 at 0.1 and $1 \mu \mathrm{M}$. It may be concluded that the ester function sensitive to metabolic hydrolysis can be advantageously replaced by a more stable amide function without dramatic decrease of biological activity.

Table 1 Effect of the new coumarin derivatives 14a-c, 15a, 16a-c and 19a-g at 0.1, 1 and $10 \mu$ M on HT 1080 fibrosarcoma cell invasion ('Boyden chamber' chemoinvasion assay) compared to the coumarins 1 and 2 and the MMP inhibitors GI 129471 and Ro 28-2653<smiles>[X]c1ccccc1[X]C(=O)c1cc2cc(COC(C)=O)ccc2oc1=O</smiles>

\begin{tabular}{|c|c|c|c|c|c|c|}
\hline Compound no. & $\mathrm{X}$ & $\mathrm{Y}$ & $\mathrm{R}$ & $0.1 \mu \mathrm{M}^{\mathrm{a}}$ & $1 \mu \mathrm{M}^{\mathrm{a}}$ & $10 \mu \mathrm{M}^{\mathrm{a}}$ \\
\hline $14 a$ & $\mathrm{~S}$ & $\mathrm{H}$ & $-\mathrm{CH}_{3}$ & $89.45 \pm 5.78$ & $83.45 \pm 6.45$ & $73.84 \pm 5.45$ \\
\hline $14 b$ & $\mathrm{~S}$ & $3-\mathrm{Cl}$ & $-\mathrm{CH}_{3}$ & $76.54 \pm 5.54$ & $65.84 \pm 3.75$ & $61.86 \pm 4.48$ \\
\hline $14 c$ & $\mathrm{~s}$ & $3-\mathrm{Br}$ & $-\mathrm{CH}_{3}$ & $79.58 \pm 7.84$ & $70.86 \pm 6.14$ & $67.84 \pm 5.58$ \\
\hline $15 a$ & $\mathrm{NH}$ & $3-\mathrm{Cl}$ & $-\mathrm{CH}_{3}$ & $79.55 \pm 2.04$ & $66.85 \pm 6.14$ & $42.75 \pm 3.58$ \\
\hline $16 a$ & $\mathrm{NCH}_{3}$ & $2-\mathrm{Cl}$ & $-\mathrm{CH}_{3}$ & n.d. ${ }^{b}$ & $62.78 \pm 5.16$ & n.d. \\
\hline $16 b$ & $\mathrm{NCH}_{3}$ & $3-\mathrm{Cl}$ & $-\mathrm{CH}_{3}$ & n.d. & $82.56 \pm 6.86$ & n.d. \\
\hline $16 c$ & $\mathrm{NCH}_{3}$ & $4-\mathrm{Cl}$ & $-\mathrm{CH}_{3}$ & n.d. & $98.56 \pm 5.12$ & n.d. \\
\hline $19 a$ & $\mathrm{O}$ & $3-\mathrm{Br}$ & $-\mathrm{CH}_{2} \mathrm{CH}_{3}$ & $84.36 \pm 2.36$ & $40.23 \pm 2.35$ & $21.32 \pm 1.96$ \\
\hline $19 b$ & $\mathrm{O}$ & $3-\mathrm{Br}$ & $-\left(\mathrm{CH}_{2}\right)_{2} \mathrm{CH}_{3}$ & $88.55 \pm 2.88$ & $50.47 \pm 2.89$ & $24.67 \pm 2.23$ \\
\hline $19 c$ & $\mathrm{O}$ & $3-\mathrm{Br}$ & $-\left(\mathrm{CH}_{2}\right)_{3} \mathrm{CH}_{3}$ & $92.36 \pm 4.42$ & $63.25 \pm 1.61$ & $32.26 \pm 0.42$ \\
\hline 19d & $\mathrm{O}$ & $3-\mathrm{Br}$ & $-\left(\mathrm{CH}_{2}\right)_{4} \mathrm{CH}_{3}$ & $94.25 \pm 2.96$ & $59.32 \pm 3.54$ & $33.94 \pm 4.01$ \\
\hline 19e & $\mathrm{O}$ & $3-\mathrm{Br}$ & $-\left(\mathrm{CH}_{2}\right)_{5} \mathrm{CH}_{3}$ & $89.36 \pm 3.25$ & $55.56 \pm 2.89$ & $35.96 \pm 6.85$ \\
\hline $19 f$ & $\mathrm{O}$ & $3-\mathrm{Br}$ & $-\mathrm{CH}\left(\mathrm{CH}_{3}\right)_{2}$ & $54.36 \pm 4.23$ & $37.80 \pm 1.64$ & $21.07 \pm 0.45$ \\
\hline $19 \mathrm{~g}$ & $\mathrm{O}$ & $3-\mathrm{Br}$ & $-\mathrm{C}\left(\mathrm{CH}_{3}\right)_{3}$ & $65.24 \pm 5.63$ & $48.21 \pm 8.32$ & $23.64 \pm 3.46$ \\
\hline $1^{\mathrm{c}}$ & $\mathrm{O}$ & $3-\mathrm{Cl}$ & $-\mathrm{CH}_{3}$ & $95.20 \pm 10.54$ & $49.11 \pm 7.64$ & $6.17 \pm 3.72$ \\
\hline $2^{c}$ & $\mathrm{O}$ & $3-\mathrm{Br}$ & $-\mathrm{CH}_{3}$ & $39.47 \pm 2.04$ & $21.81 \pm 7.14$ & $11.77 \pm 1.24$ \\
\hline GI 129471 & & & & n.d. & $38.45 \pm 2.36$ & n.d. \\
\hline Ro 28-2653 & & & & n.d. & $41.60 \pm 4.35$ & n.d. \\
\hline
\end{tabular}

${ }^{a}$ Results are expressed as the number of migrated cells in \% of control (100\%) corresponding to the assay in the absence of tested compound (mean \pm s.d., $n \geq 3$ ).

${ }^{\mathrm{b}}$ n.d.: Not determined.

${ }^{\mathrm{c}}$ Published results (Ref. [10]). 
('Boyden chamber' chemoinvasion assay) compared to coumarins 1, 2, 31, 32 and 25c and the MMP inhibitor GI 129471

\begin{tabular}{|c|c|c|c|c|c|}
\hline Compound no. & $\mathrm{X}$ & $\mathrm{Y}$ & $0.1 \mu \mathrm{M}^{\mathrm{a}}$ & $1 \mu \mathrm{M}^{\mathrm{a}}$ & $10 \mu \mathrm{M}^{\mathrm{a}}$ \\
\hline$\overline{24 a}$ & $-\mathrm{NO}_{2}$ & $-\mathrm{H}$ & n.d $d^{b}$ & $76.68 \pm 5.64$ & n.d. \\
\hline $24 b$ & $-\mathrm{NO}_{2}$ & $-F$ & n.d. & $53.56 \pm 2.04$ & n.d. \\
\hline $24 c$ & $-\mathrm{NO}_{2}$ & $-\mathrm{Cl}$ & n.d. & $65.78 \pm 5.16$ & n.d. \\
\hline 24d & $-\mathrm{NO}_{2}$ & $-\mathrm{Br}$ & n.d. & $35.22 \pm 4.13$ & n.d. \\
\hline $24 e$ & $-\mathrm{NO}_{2}$ & $-\mathrm{I}$ & n.d. & $63.58 \pm 5.12$ & n.d. \\
\hline $27 a$ & $-\mathrm{CH}_{2} \mathrm{NH}_{2}$ & $-\mathrm{H}$ & n.d. & $85.53 \pm 6.54$ & n.d. \\
\hline $27 b$ & $-\mathrm{CH}_{2} \mathrm{NH}_{2}$ & $-F$ & n.d. & $45.25 \pm 7.14$ & n.d. \\
\hline $27 c$ & $-\mathrm{CH}_{2} \mathrm{NH}_{2}$ & $-\mathrm{Cl}$ & n.d. & $86.56 \pm 4.13$ & n.d. \\
\hline 27d & $-\mathrm{CH}_{2} \mathrm{NH}_{2}$ & $-\mathrm{Br}$ & $88.26 \pm 5.12$ & $79.25 \pm 7.15$ & $63.58 \pm 6.32$ \\
\hline $27 e$ & $-\mathrm{CH}_{2} \mathrm{NH}_{2}$ & $-\mathrm{I}$ & n.d. & $25.34 \pm 7.15$ & n.d. \\
\hline $28 a$ & $-\mathrm{CH}_{2} \mathrm{NHCOCH}_{3}$ & $-\mathrm{H}$ & n.d. & $63.45 \pm 5.54$ & n.d. \\
\hline $28 b$ & $-\mathrm{CH}_{2} \mathrm{NHCOCH}_{3}$ & $-F$ & n.d. & $65.58 \pm 1.24$ & n.d. \\
\hline $28 c$ & $-\mathrm{CH}_{2} \mathrm{NHCOCH}_{3}$ & $-\mathrm{Cl}$ & n.d. & $36.58 \pm 0.86$ & n.d. \\
\hline 28d & $-\mathrm{CH}_{2} \mathrm{NHCOCH}_{3}$ & $-\mathrm{Br}$ & $34.38 \pm 3.44$ & $36.94 \pm 5.34$ & $27.14 \pm 4.50$ \\
\hline $28 e$ & $-\mathrm{CH}_{2} \mathrm{NHCOCH}_{3}$ & $-\mathrm{I}$ & n.d. & $23.47 \pm 6.32$ & n.d. \\
\hline $31^{\mathrm{c}}$ & $-\mathrm{H}$ & $-\mathrm{Cl}$ & $52.40 \pm 11.13$ & $45.50 \pm 9.97$ & $35.65 \pm 6.94$ \\
\hline $32^{\mathrm{c}}$ & $-\mathrm{CH}_{3}$ & $-\mathrm{Cl}$ & $81.50 \pm 5.12$ & $52.49 \pm 1.44$ & $27.62 \pm 1.50$ \\
\hline $25 c^{c}$ & $-\mathrm{CH}_{2} \mathrm{Cl}$ & $-\mathrm{Cl}$ & $98.35 \pm 5.47$ & $79.76 \pm 8.71$ & $67.00 \pm 7.73$ \\
\hline 1 & $-\mathrm{CH}_{2} \mathrm{OCOCH}_{3}$ & $-\mathrm{Cl}$ & $95.20 \pm 10.54$ & $49.11 \pm 7.64$ & $6.17 \pm 3.72$ \\
\hline $\begin{array}{l}2 \\
\text { GI 129471 }\end{array}$ & $-\mathrm{CH}_{2} \mathrm{OCOCH}_{3}$ & $-\mathrm{Br}$ & $\begin{array}{l}39.47 \pm 2.04 \\
\text { n.d. }\end{array}$ & $\begin{array}{l}21.81 \pm 7.14 \\
38.45 \pm 2.36\end{array}$ & $\begin{array}{l}11.77 \pm 1.24 \\
\text { n.d. }\end{array}$ \\
\hline
\end{tabular}

${ }^{a}$ Results are expressed as the number of migrated cells in \% of control (100\%) corresponding to the assay in the absence of tested compound (mean \pm s.d., $n \geq 3$ ).

${ }^{b}$ n.d.: Not determined.

${ }^{\mathrm{c}}$ Published results (Ref. [10]).

\section{Conclusion}

The present work aimed at describing new examples of coumarin-3-carboxylic acid derivatives structurally related to lead coumarins $\mathbf{1}$ and $\mathbf{2}$ expressing anti-invasive activity in vitro and anti-tumoral effect in vivo. Among the different chemical modifications examined, the replacement of the ester function in the 6-position of $\mathbf{1}$ and $\mathbf{2}$ by an amide function was allowed without loss of potency in the 'Boyden chamber' chemoinvasion assay with HT 1080 fibrosarcoma cells. By contrast, an aryl ester function in the 3-position was strongly recommended since its replacement by a thioester or an amide function was responsible for a significant decrease of the antiinvasive activity.

The increase of the size of the alkyl chain located on the acyloxymethyl moiety in the 6-position reduced the anti-invasive activity, although a short branched chain such as an isopropyl or a tert-butyl chain was allowed without markedly reducing the activity in the chemoinvasion assay.

\section{Experimental protocols}

\subsection{Chemistry}

Melting points were determined with a Büchi-Tottoli capillary apparatus and are uncorrected. IR spectra were recorded as $\mathrm{KBr}$ pellets on a Perkin-Elmer 1000FTIR spectrophotometer. The ${ }^{1} \mathrm{H}$ NMR spectra were recorded on a Bruker AW-80 (80 MHz) or a Bruker Avance (500 MHz) instrument using $d_{6}$-DMSO as the solvent with TMS as an internal standard; chemical shifts are reported in $\delta$ values (ppm) relative to that of internal TMS. The abbreviations $\mathrm{s}=$ singlet, $\mathrm{d}=$ doublet, $\mathrm{t}=$ triplet, $\mathrm{q}=$ quadruplet, $\mathrm{m}=$ multiplet, and $\mathrm{b}=$ broad are used throughout. Elemental analysis $(\mathrm{C}, \mathrm{H}, \mathrm{N}$, and $\mathrm{S})$ was realized on a Carlo-Erba EA 1108-elemental analyser and was within $\pm 0.4 \%$ of the theoretical values. All reactions were routinely checked by TLC on silica gel Merck 60 $\mathrm{F}_{254}$. 
GI129471 was synthesized by Roche Diagnostics according to the PCT Patent Applications WO 90/05719. Ro 28-2653 was obtained according to a synthetic route described in the literature [24].

6-Hydroxymethyl-2-oxo-2H-1-benzopyran-3-carboxylic acid (11), 6-acetoxymethyl-2-oxo-2H-1-benzopyran-3carboxylic acid (12), phenyl 6-chloromethyl-2-oxo-2H-1-benzopyran-3-carboxylate (25a), 3-fluorophenyl 6chloromethyl-2-oxo-2 $\mathrm{H}$-1-benzopyran-3-carboxylate (25b), 3-chlorophenyl 6-chloromethyl-2-oxo-2H-1benzopyran-3-carboxylate (25c), 3-bromophenyl 6-chloromethyl-2-oxo-2H-1-benzopyran-3-carboxylate (25d) and 3-iodophenyl 6-chloromethyl-2-oxo-2H-1-benzopyran-3-carboxylate (25e) were obtained according to previously described procedures [21,23].

\subsection{General procedure for the preparation of the 6-acyloxymethyl-2-oxo-2H-1-benzopyran-3-carboxylic acids} (17a-g)

Three grams of 6-hydroxymethyl-2-oxo- $2 H$-1-benzopyran-3-carboxylic acid (11) were refluxed with the appropriate anhydride for $3 \mathrm{~h}$. After cooling, $200 \mathrm{~mL}$ of distilled water were added and the suspension was stirred overnight. The resulting precipitate was collected by filtration, washed with distilled water and dried. The crude product was then crystallized in the appropriate solvent (yields: 60-80\%).

\subsubsection{6-Propionoxymethyl-2-oxo-2H-1-benzopyran-3-carboxylic acid (17a)}

The title compound was obtained as described above after the reaction of $\mathbf{1 1}$ with propionic anhydride $(30 \mathrm{~mL})$. The crude product was crystallized in $\mathrm{CHCl}_{3}$ :petroleum ether $40-60^{\circ} \mathrm{C}$ : $\mathrm{mp} 174-176.5^{\circ} \mathrm{C}$; IR $3055(\mathrm{C}-\mathrm{H}$ arom $)$, $1754(\mathrm{C}=\mathrm{O}$ ester $), 1741(\mathrm{C}=\mathrm{O}$ lactone $), 1689(\mathrm{C}=\mathrm{O}$ carboxylic acid $), 1622,1577,1414,1378 \mathrm{~cm}^{-1} ;{ }^{1} \mathrm{H}$ NMR $1.18\left(\mathrm{t}, 3 \mathrm{H}, \mathrm{CH}_{3}\right), 2.42$ (q, 2H, $\left.\mathrm{CH}_{2} \mathrm{CH}_{3}\right), 5.21\left(\mathrm{~s}, 2 \mathrm{H}, \mathrm{CH}_{2} \mathrm{OCOC}_{2} \mathrm{H}_{5}\right), 7.50(\mathrm{~d}, 1 \mathrm{H}, 8-\mathrm{H}), 7.75(\mathrm{~s}, 1 \mathrm{H}, 5-\mathrm{H}), 7.77$ $(\mathrm{d}, 1 \mathrm{H}, 7-\mathrm{H}), 8.94$ (s, 1H, 4-H). Anal. $\mathrm{C}_{14} \mathrm{H}_{12} \mathrm{O}_{6}(\mathrm{C}, \mathrm{H})$.

\subsubsection{6-Butyryloxymethyl-2-oxo-2H-1-benzopyran-3-carboxylic acid (17b)}

The title compound was obtained as described above after the reaction of $\mathbf{1 1}$ with butyric anhydride $(30 \mathrm{~mL})$. The crude product was crystallized in $\mathrm{CH}_{3} \mathrm{CN}$ :water: $\mathrm{mp} 146-147.5^{\circ} \mathrm{C}$; IR $3046(\mathrm{C}-\mathrm{H}$ arom $), 1740(\mathrm{C}=\mathrm{O}$ lactone and ester), $1692\left(\mathrm{C}=\mathrm{O}\right.$ carboxylic acid), 1626, 1581, 1415, $1372 \mathrm{~cm}^{-1} ;{ }^{1} \mathrm{H}$ NMR $0.96(\mathrm{t}, 3 \mathrm{H}, \mathrm{CH}), 1.68(\mathrm{~m}, 2 \mathrm{H}$, $\left.\mathrm{CH}_{2} \mathrm{CH}_{2} \mathrm{CH}_{3}\right), 2.37$ (t, 2H, $\left.\mathrm{CH}_{2} \mathrm{CH}_{2} \mathrm{CH}_{3}\right), 5.19$ (s, $\left.2 \mathrm{H}, \mathrm{CH}_{2} \mathrm{OCO}\left(\mathrm{CH}_{2}\right)_{2} \mathrm{CH}_{3}\right), 7.49(\mathrm{~d}, 1 \mathrm{H}, 8-\mathrm{H}), 7.71(\mathrm{~d}, 1 \mathrm{H}, 7-$ $\mathrm{H}), 7.75$ (s, 1H, 5-H), 8.94 (s, 1H, 4-H). Anal. $\mathrm{C}_{15} \mathrm{H}_{14} \mathrm{O}_{6}(\mathrm{C}, \mathrm{H})$.

\subsubsection{6-Valeryloxymethyl-2-oxo-2H-1-benzopyran-3-carboxylic acid (17c)}

The title compound was obtained as described above after the reaction of $\mathbf{1 1}$ with valeric anhydride $(30 \mathrm{~mL})$. The crude product was crystallized in $\mathrm{CHCl}_{3}$ :diisopropylether: mp $108.5-109^{\circ} \mathrm{C}$; IR $3055(\mathrm{C}-\mathrm{H}$ arom $), 1741(\mathrm{C}=\mathrm{O}$ lactone and ester), 1689 (C=O carboxylic acid), 1624, 1578, 1409, $1375 \mathrm{~cm}^{-1}$; ${ }^{1} \mathrm{H}$ NMR $0.88\left(\mathrm{t}, 3 \mathrm{H}, \mathrm{CH}_{3}\right), 1.42$ $\left(\mathrm{m}, 2 \mathrm{H}, \mathrm{CH}_{2} \mathrm{CH}_{3}\right), 1.55\left(\mathrm{~m}, 2 \mathrm{H}, \mathrm{CH}_{2} \mathrm{CH}_{2} \mathrm{CH}_{3}\right), 2.35\left(\mathrm{t}, 2 \mathrm{H}, \mathrm{CH}_{2} \mathrm{CH}_{2} \mathrm{CH}_{2} \mathrm{CH}_{3}\right), 5.20\left(\mathrm{~s}, 2 \mathrm{H}, \mathrm{CH}_{2} \mathrm{OCO}\left(\mathrm{CH}_{2}\right)_{3} \mathrm{CH}_{3}\right)$, $7.50(\mathrm{~d}, 1 \mathrm{H}, 8-\mathrm{H}), 7.78(\mathrm{~d}, 1 \mathrm{H}, 7-\mathrm{H}), 7.97$ (s, 1H, 5-H), $8.96(\mathrm{~s}, 1 \mathrm{H}, 4-\mathrm{H})$. Anal. $\mathrm{C}_{16} \mathrm{H}_{16} \mathrm{O}_{6}(\mathrm{C}, \mathrm{H})$.

\subsubsection{6-Hexanoyloxymethyl-2-oxo-2H-1-benzopyran-3-carboxylic acid (17d)}

The title compound was obtained as described above after the reaction of 11 with hexanoic anhydride $(20 \mathrm{~mL})$. The crude product was crystallized in $\mathrm{CH}_{3} \mathrm{CN}$ :water: mp 103-105.5 ${ }^{\circ} \mathrm{C}$; IR $3052(\mathrm{C}-\mathrm{H}$ arom $), 1740(\mathrm{C}=\mathrm{O}$ lactone \& ester), $1697\left(\mathrm{C}=\mathrm{O}\right.$ carboxylic acid), 1625, 1579, 1414, $1375 \mathrm{~cm}^{-1} ;{ }^{1} \mathrm{H}$ NMR 0.85 (t, 3H, $\left.\mathrm{CH}_{3}\right), 1.24$ (m, 4H, $\left.\mathrm{CH}_{2} \mathrm{CH}_{2} \mathrm{CH}_{3}\right), 1.56\left(\mathrm{~m}, 2 \mathrm{H}, \mathrm{CH}_{2}\left(\mathrm{CH}_{2}\right)_{2} \mathrm{CH}_{3}\right), 2.35\left(\mathrm{t}, 2 \mathrm{H}, \mathrm{CH}_{2}\left(\mathrm{CH}_{2}\right)_{3} \mathrm{CH}_{3}\right), 5.20\left(\mathrm{~s}, 2 \mathrm{H}, \mathrm{CH}_{2} \mathrm{OCO}\left(\mathrm{CH}_{2}\right)_{4} \mathrm{CH}_{3}\right)$, $7.54(\mathrm{~d}, 1 \mathrm{H}, 8-\mathrm{H}), 7.78(\mathrm{~d}, 1 \mathrm{H}, 7-\mathrm{H}), 7.97$ (s, 1H, 5-H), $9.02(\mathrm{~s}, 1 \mathrm{H}, 4-\mathrm{H})$. Anal. $\mathrm{C}_{17} \mathrm{H}_{18} \mathrm{O}_{6}(\mathrm{C}, \mathrm{H})$.

\subsubsection{6-Heptanoyloxymethyl-2-oxo-2H-1-benzopyran-3-carboxylic acid (17e)}

The title compound was obtained as described above after the reaction of 11 with heptanoic anhydride $(35 \mathrm{~mL})$. The crude product was crystallized in $\mathrm{CHCl}_{3}$ :petroleum ether $40-60^{\circ} \mathrm{C}$ : mp $102-102.5^{\circ} \mathrm{C}$; IR $3055(\mathrm{C}-\mathrm{H}$ arom), $1743\left(\mathrm{C}=\mathrm{O}\right.$ lactone and ester), $1690(\mathrm{C}=\mathrm{O}$ carboxylic acid $), 1624,1578,1410,1375 \mathrm{~cm}^{-1} ;{ }^{1} \mathrm{H}$ NMR $0.88(\mathrm{t}, 3 \mathrm{H}$, $\left.\mathrm{CH}_{3}\right), 1.24\left(\mathrm{~m}, 6 \mathrm{H},\left(\mathrm{CH}_{2}\right)_{3} \mathrm{CH}_{3}\right), 1.55\left(\mathrm{~m}, 2 \mathrm{H}, \mathrm{CH}_{2}\left(\mathrm{CH}_{2}\right)_{3} \mathrm{CH}_{3}\right), 2.38\left(\mathrm{t}, 2 \mathrm{H}, \mathrm{CH}_{2}\left(\mathrm{CH}_{2}\right)_{4} \mathrm{CH}_{3}\right), 5.20(\mathrm{~s}, 2 \mathrm{H}$, $\left.\mathrm{CH}_{2} \mathrm{OCO}\left(\mathrm{CH}_{2}\right)_{5} \mathrm{CH}_{3}\right), 7.46(\mathrm{~d}, 1 \mathrm{H}, 8-\mathrm{H}), 7.78(\mathrm{~d}, 1 \mathrm{H}, 7-\mathrm{H}), 7.97(\mathrm{~s}, 1 \mathrm{H}, 5-\mathrm{H}), 9.04(\mathrm{~s}, 1 \mathrm{H}, 4-\mathrm{H})$. Anal. $\mathrm{C}_{18} \mathrm{H}_{20} \mathrm{O}_{6}$ $(\mathrm{C}, \mathrm{H})$.

\subsubsection{6-Dimethylacetoxymethyl-2-oxo-2H-1-benzopyran-3-carboxylic acid (17f)}

The title compound was obtained as described above after the reaction of 11 with isobutyric anhydride $(30 \mathrm{~mL})$. The crude product was crystallized in $\mathrm{CHCl}_{3}$ :petroleum ether $40-60^{\circ} \mathrm{C}$ : $\mathrm{mp} 134-135^{\circ} \mathrm{C}$; IR 3049 (C-H arom), $1753(\mathrm{C}=\mathrm{O}$ ester $), 1726(\mathrm{C}=\mathrm{O}$ lactone $), 1684(\mathrm{C}=\mathrm{O}$ carboxylic acid $), 1620,1576,1416,1386 \mathrm{~cm}^{-1} ;{ }^{1} \mathrm{H}$ NMR $1.20\left(\mathrm{~d}, 6 \mathrm{H},\left(\mathrm{CH}_{3}\right)_{2}\right), 2.63(\mathrm{q}, 1 \mathrm{H}, \mathrm{CH}), 5.20\left(\mathrm{~s}, 2 \mathrm{H}, \mathrm{CH}_{2}\right), 7.49(\mathrm{~d}, 1 \mathrm{H}, 8-\mathrm{H}), 7.74(\mathrm{~s}, 1 \mathrm{H}, 5-\mathrm{H}), 7.76(\mathrm{~d}, 1 \mathrm{H}, 7-\mathrm{H})$, $8.94(\mathrm{~s}, 1 \mathrm{H}, 4-\mathrm{H})$. Anal. $\mathrm{C}_{15} \mathrm{H}_{14} \mathrm{O}_{6}(\mathrm{C}, \mathrm{H})$. 


\subsubsection{6-Trimethylacetoxymethyl-2-oxo-2H-1-benzopyran-3-carboxylic acid (17g)}

The title compound was obtained as described above after the reaction of 11 with pivaloic anhydride $(30 \mathrm{~mL})$. The crude product was crystallized in $\mathrm{CHCl}_{3}$ :petroleum ether $40-60{ }^{\circ} \mathrm{C}$ : $\mathrm{mp} 136-137.5^{\circ} \mathrm{C}$; IR $3044(\mathrm{C}-\mathrm{H}$ arom), 2969 (C-H aliph), 1743 (C=O lactone and ester), 1674 (C=O carboxylic acid), 1620, 1575, 1417, $1157 \mathrm{~cm}^{-1} ;{ }^{1} \mathrm{H}$ NMR $1.24\left(\mathrm{~s}, 9 \mathrm{H},\left(\mathrm{CH}_{3}\right)_{3}\right), 5.20\left(\mathrm{~s}, 2 \mathrm{H}, \mathrm{CH}_{2}\right), 7.50(\mathrm{~d}, 1 \mathrm{H}, 8-\mathrm{H}), 7.74(\mathrm{~s}, 1 \mathrm{H}, 5-\mathrm{H}), 7.76(\mathrm{~d}, 1 \mathrm{H}, 7-\mathrm{H}), 8.95(\mathrm{~s}$, $1 \mathrm{H}, 4-\mathrm{H})$. Anal. $\mathrm{C}_{16} \mathrm{H}_{16} \mathrm{O}_{6}(\mathrm{C}, \mathrm{H})$.

\subsubsection{Ethyl 6-nitro-2-oxo-2H-1-benzopyran-3-carboxylate (21)}

A mixture of 5-nitro-salicylaldehyde (20) (1 g, $5.98 \mathrm{mmol})$, diethyl malonate $(1.05 \mathrm{~g}, 6.59 \mathrm{mmol})$, piperidine $(0.076 \mathrm{~mL})$ and acetic acid $(0.03 \mathrm{~mL})$ in ethanol $(4 \mathrm{~mL})$ was heated under reflux for $18 \mathrm{~h}$. The resulting precipitate was collected by filtration and washed with ethanol. The crude product was suspended in methanol, collected by filtration, washed with methanol and dried (yield: 64\%): mp 195.5-196.5; IR 3078, 3056 (C-H arom), 1779 (C=O ester), 1757 ( $\mathrm{C}=\mathrm{O}$ lactone), 1692, 1619, 1570, 1528, 1348, $1256 \mathrm{~cm}^{-1} ;{ }^{1} \mathrm{H}$ NMR 1.33 (t, 3H, $\left.\mathrm{CH}_{3}\right), 4.33\left(\mathrm{q}, 2 \mathrm{H}, \mathrm{CH}_{2}\right), 7.66(\mathrm{~d}, 1 \mathrm{H}, 8-\mathrm{H}), 8.51(\mathrm{~d}, 1 \mathrm{H}, 7-\mathrm{H}), 8.93-8.94(\mathrm{~m}, 2 \mathrm{H}, 4-\mathrm{H}, 5-\mathrm{H})$. Anal. $\mathrm{C}_{12} \mathrm{H}_{9} \mathrm{NO}_{6}(\mathrm{C}$, $\mathrm{H}, \mathrm{N})$.

\subsubsection{6-Nitro-2-oxo-2H-1-benzopyran-3-carboxylic acid (22)}

The suspension of ethyl 6-nitro-2-oxo-2H-1-benzopyran-3-carboxylate (21) (5 g, $18.9 \mathrm{mmol})$ in 10\% aqueous $\mathrm{NaOH}(150 \mathrm{~mL})$ was heated under reflux for $30 \mathrm{~min}$. After cooling, $\mathrm{pH}$ was adjusted to 1 by $12 \mathrm{~N} \mathrm{HCl}$, while stirring over an ice bath. The resulting precipitate was collected by filtration, washed with distilled water and crystallized in $\mathrm{CH}_{3} \mathrm{CN}$ (yield: 91\%): $\mathrm{mp} 229.5-230^{\circ} \mathrm{C}$; IR $3116,3076(\mathrm{C}-\mathrm{H}$ arom), 1723 (C=O lactone and carboxylic acid), 1617, 1536, 1523, 1354, 1233, $1208 \mathrm{~cm}^{-1} ;{ }^{1} \mathrm{H}$ NMR $7.65(\mathrm{~d}, 1 \mathrm{H}, 8-\mathrm{H}), 8.50(\mathrm{~d}, 1 \mathrm{H}, 7-\mathrm{H}), 8.90$ $(\mathrm{s}, 1 \mathrm{H}, 4-\mathrm{H}), 8.91(\mathrm{~s}, 1 \mathrm{H}, 5-\mathrm{H}), 13.51(\mathrm{~s}, 1 \mathrm{H}, \mathrm{COOH})$. Anal. $\mathrm{C}_{10} \mathrm{H}_{5} \mathrm{NO}_{6}(\mathrm{C}, \mathrm{H}, \mathrm{N})$.

5.3. General procedure for the preparation of the thioesters (14), the secondary (15) and tertiary (16) amides of 6-acetoxymethyl-2-oxo-2H-1-benzopyran-3-carboxylic acid, the esters of 6-acyloxymethyl-2-oxo-2H-1benzopyran-3-carboxylic acid (19) and 6-nitro-2-oxo-2H-1-benzopyran-3-carboxylic acid (24)

The appropriate carboxylic acid $(1 \mathrm{~g})$ was refluxed in thionyl chloride $(10 \mathrm{~mL})$ for $3 \mathrm{~h}$. The resulting solution was concentrated to dryness under reduced pressure and the residue was dispersed in dry toluene $(10 \mathrm{~mL})$. The solvent was eliminated under reduced pressure. Dispersion in dry toluene and solvent elimination was repeated twice. The residue was dispersed in anhydrous dioxane $(3 \mathrm{~mL})$ and added with stirring to a solution of the appropriate phenol, thiophenol or aniline and anhydrous pyridine in anhydrous dioxane. The progress of the reaction was followed by TLC. Yields are usually comprised between 50\% and 80\%.

\subsubsection{S-Phenyl 6-acetoxymethyl-2-oxo-2H-1-benzopyran-3-carbothioate (14a)}

The title compound was obtained as described in the general procedure after the reaction of the acyl chloride of 6-acetoxymethyl-2-oxo-2H-1-benzopyran-3-carboxylic acid (13) ( 3.8 mmol) with thiophenol (0.49 g, 4.5 $\mathrm{mmol})$ and pyridine $(1 \mathrm{~mL}, 12.5 \mathrm{mmol})$. After stirring overnight at room temperature, the solvents were eliminated by distillation under reduced pressure. The residue was dissolved in warm ethyl acetate and the solution was treated with charcoal. After reducing the volume of the filtrate, precipitation was obtained by addition of petroleum ether $40-60^{\circ} \mathrm{C}$. The crude product was crystallized twice in ethyl acetate: $\mathrm{mp} 140.5-142^{\circ} \mathrm{C}$; IR 3047 (C-H arom), 1729 (C=O lactone and ester), $1662\left(\mathrm{C}=\mathrm{O}\right.$ thioester), 1568, $1182 \mathrm{~cm}^{-1}$; ${ }^{1} \mathrm{H}$ NMR 2.09 (s, $\left.3 \mathrm{H}, \mathrm{CH}_{3}\right), 5.16\left(\mathrm{~s}, 2 \mathrm{H}, \mathrm{CH}_{2}\right), 7.54-7.53\left(\mathrm{~m}, 6 \mathrm{H}, 8-\mathrm{H}, \mathrm{C}_{6} \mathrm{H}_{5}\right), 7.79(\mathrm{~d}, 1 \mathrm{H}, 7-\mathrm{H}), 8.01(\mathrm{~s}, 1 \mathrm{H}, 5-\mathrm{H}), 8.81(\mathrm{~s}, 1 \mathrm{H}, 4-$ H). Anal. $\mathrm{C}_{19} \mathrm{H}_{14} \mathrm{O}_{5} \mathrm{~S}(\mathrm{C}, \mathrm{H}, \mathrm{S})$.

\subsubsection{S-3-Chlorophenyl 6-acetoxymethyl-2-oxo-2H-1-benzopyran-3-carbothioate (14b)}

The title compound was obtained as described in the general procedure after the reaction of the acyl chloride of 6-acetoxymethyl-2-oxo-2H-1-benzopyran-3-carboxylic acid (13) $(\sim 3.8 \mathrm{mmol})$ with 3-chlorothiophenol $(0.65 \mathrm{~g}$, $4.5 \mathrm{mmol})$ and pyridine $(1 \mathrm{~mL}, 12.5 \mathrm{mmol})$. After stirring overnight at room temperature, the solvents were eliminated by distillation under reduced pressure. The residue was dissolved in warm ethyl acetate and the solution was treated with charcoal. After reducing the volume of the filtrate, precipitation was obtained by addition of petroleum ether $40-60^{\circ} \mathrm{C}$. The crude product was crystallized twice in ethyl acetate: mp $135.5-137^{\circ} \mathrm{C}$; IR $3066(\mathrm{C}-\mathrm{H}$ arom $), 1738(\mathrm{C}=\mathrm{O}$ ester $), 1728(\mathrm{C}=\mathrm{O}$ lactone $), 1656(\mathrm{C}=\mathrm{O}$ thioester $), 1569,1181 \mathrm{~cm}^{-1} ;{ }^{1} \mathrm{H} \mathrm{NMR}$ 2.08 (s, 3H, $\left.\mathrm{CH}_{3}\right), 5.16$ (s, 2H, $\left.\mathrm{CH}_{2}\right), 7.49$ (d, 1H, 4'-H), 7.53-7.55 (m, 2H, 8-H, 5'-H), 7.59-7.61 (m, 2'-H, 6'-H), $7.80(\mathrm{~d}, 1 \mathrm{H}, 7-\mathrm{H}), 8.02(\mathrm{~s}, 1 \mathrm{H}, 5-\mathrm{H}), 8.83(\mathrm{~s}, 1 \mathrm{H}, 4-\mathrm{H})$. Anal. $\mathrm{C}_{19} \mathrm{H}_{13} \mathrm{O}_{5} \mathrm{SCl}(\mathrm{C}, \mathrm{H}, \mathrm{S})$.

\subsubsection{S-3-Bromophenyl 6-acetoxymethyl-2-oxo-2H-1-benzopyran-3-carbothioate (14c)}

The title compound was obtained as described in the general procedure after the reaction of the acyl chloride of 6-acetoxymethyl-2-oxo-2H-1-benzopyran-3-carboxylic acid (13) $(\sim 3.8 \mathrm{mmol})$ with 3-bromothiophenol $(0.85 \mathrm{~g}$, $4.5 \mathrm{mmol})$ and pyridine $(1 \mathrm{~mL}, 12.5 \mathrm{mmol})$. After stirring overnight at room temperature, the solvents were 
eliminated by distillation under reduced pressure. The residue was dissolved in warm ethyl acetate and the solution was treated with charcoal. After reducing the volume of the filtrate, precipitation was obtained by addition of petroleum ether $40-60^{\circ} \mathrm{C}$. The crude product was crystallized twice in ethyl acetate: $\mathrm{mp} 129.5$ $132.5^{\circ} \mathrm{C}$; IR 3062 (C-H arom), $1736\left(\mathrm{C}=\mathrm{O}\right.$ ester), $1725(\mathrm{C}=\mathrm{O}$ lactone $), 1657(\mathrm{C}=\mathrm{O}$ thioester $), 1568,1181 \mathrm{~cm}^{-1}$; ${ }^{1} \mathrm{H}$ NMR 2.09 (s, 3H, CH $), 5.16\left(\mathrm{~s}, 2 \mathrm{H}, \mathrm{CH}_{2}\right), 7.48\left(\mathrm{~d}, 1 \mathrm{H}, 6{ }^{\prime}-\mathrm{H}\right), 7.52-7.56(\mathrm{~m}, 2 \mathrm{H}, 8-\mathrm{H}, 5$ '- $\mathrm{H}), 7.72-7.74(\mathrm{~m}$, 2'-H, 4'-H), 7.80 (d, 1H, 7-H), $8.02(\mathrm{~s}, 1 \mathrm{H}, 5-\mathrm{H}), 8.83$ (s, 1H, 4-H). Anal. $\mathrm{C}_{19} \mathrm{H}_{13} \mathrm{O}_{5} \mathrm{SBr}(\mathrm{C}, \mathrm{H}, \mathrm{S})$.

\subsubsection{N-3-Chlorophenyl 6-acetoxymethyl-2-oxo-2H-1 -benzopyran-3-carboxamide (15a)}

The title compound was obtained as described in the general procedure after the reaction of the acyl chloride of 6-acetoxymethyl-2-oxo-2H-1-benzopyran-3-carboxylic acid (13) $(\sim 3.8 \mathrm{mmol})$ with 3-chloroaniline $(0.63 \mathrm{~g}, 5$ $\mathrm{mmol})$ and pyridine $(1 \mathrm{~mL}, 12.5 \mathrm{mmol})$. After $6 \mathrm{~h}$ at room temperature, the resulting precipitate was collected by filtration and washed with dioxane. The crude product was dissolved in $\mathrm{CHCl}_{3}$ and treated with charcoal, then cyclohexane was added and the resulting precipitate was collected by filtration and dried: $\mathrm{mp} 187-190^{\circ} \mathrm{C}$; IR 3263, 3124 (C-H arom), 1742 ( $\mathrm{C}=\mathrm{O}$ lactone and ester), $1699(\mathrm{C}=\mathrm{O}$ amide) $, 1617,1591,1575,1541,1427,1240$ $\mathrm{cm}^{-1}$; ${ }^{1} \mathrm{H}$ NMR $2.10\left(\mathrm{~s}, 3 \mathrm{H}, \mathrm{CH}_{3}\right), 5.17\left(\mathrm{~s}, 2 \mathrm{H}, \mathrm{CH}_{2}\right), 7.21(\mathrm{~d}, 1 \mathrm{H}, 8-\mathrm{H}), 7.42(\mathrm{t}, 1 \mathrm{H}, 5 \mathrm{\prime}-\mathrm{H}), 7.56-7.59(\mathrm{~m}, 2 \mathrm{H}, 8-\mathrm{H}$, 4'-H), 7.77 (d, 1H, 7-H), 7.99 (d, 2H, 2'H, 6'-H), 8.89 (s, 1H, 4-H), 10.75 (s, 1H, NH). Anal. $\mathrm{C}_{19} \mathrm{H}_{14} \mathrm{O}_{5} \mathrm{NCl}(\mathrm{C}, \mathrm{H}$, $\mathrm{N})$.

\subsubsection{N-methyl-N-(2-chlorophenyl)-6-acetoxymethyl-2-oxo-2H-1-benzopyran-3 -carboxamide (16a)}

The title compound was obtained as described in the general procedure after the reaction of the acyl chloride of 6-acetoxymethyl-2-oxo-2 $\mathrm{H}$-1-benzopyran-3-carboxylic acid (13) $(\sim 3.8 \mathrm{mmol})$ with 2-chloro- $N$-methylaniline $(0.7 \mathrm{~g}, 5 \mathrm{mmol})$ and pyridine $(1 \mathrm{~mL}, 12.5 \mathrm{mmol})$. After $6 \mathrm{~h}$ at room temperature, water was added and the mixture was cooled on an ice bath, then the resulting precipitate was collected by filtration and dried: mp 119$121^{\circ} \mathrm{C}$; IR 3061, $2938(\mathrm{C}-\mathrm{H}$ arom), 1732 ( $\mathrm{C}=\mathrm{O}$ lactone and ester), 1648 ( $\mathrm{C}=\mathrm{O}$ amide), 1623, 1580, 1486, 1233 $\mathrm{cm}^{-1} ;{ }^{1} \mathrm{H}$ NMR 2.09 (s, 3H, CH $\left.\mathrm{CH}_{3}\right), 3.24$ (s, 3H, $\left.\mathrm{NCH}_{3}\right), 5.09$ (s, 2H, CH $), 7.28-7.33$ (m, 2H, 4'-H, 8-H), 7.46-7.49 (m, 3H, 3'-H, 5'-H, 7-H), 7.59 (d, 1H, 6'-H), 7.73 (s, 1H, 5-H), 8.23 (s, 1H, 4-H). Anal. $\mathrm{C}_{20} \mathrm{H}_{16} \mathrm{O}_{5} \mathrm{NCl}(\mathrm{C}, \mathrm{H}, \mathrm{N})$.

\subsubsection{N-Methyl-N-(3-chlorophenyl)-6-acetoxymethyl-2-oxo-2H-1-benzopyran-3-carboxamide (16b)}

The title compound was obtained as described in the general procedure after the reaction of the acyl chloride of 6-acetoxymethyl-2-oxo-2H-1-benzopyran-3-carboxylic acid (13) ( 3.8 mmol) with 3-chloro- $N$-methylaniline $(0.7 \mathrm{~g}, 5 \mathrm{mmol})$ and pyridine $(1 \mathrm{~mL}, 12.5 \mathrm{mmol})$. After $8 \mathrm{~h}$ at room temperature, the resulting precipitate was collected by filtration and washed with dioxane. The crude product was crystallized twice in methanol: mp 106$108^{\circ} \mathrm{C}$; IR 3062, 2963 (C-H arom), 1729 (C=O lactone and ester), 1648 (C=O amide), 1623, 1591, 1580, 1481, $1230 \mathrm{~cm}^{-1}$; ${ }^{1} \mathrm{H}$ NMR 2.07 (s, 3H, $\left.\mathrm{CH}_{3}\right), 3.33$ (s, 3H, NCH$), 5.12\left(\mathrm{~s}, 2 \mathrm{H}, \mathrm{CH}_{2}\right), 7.25\left(\mathrm{~m}, 1 \mathrm{H}, 4^{\prime}-\mathrm{H}\right), 7.30(\mathrm{~m}, 2 \mathrm{H}$, 5'-H, 8-H), 7.37 (m, 1H, 7-H), 7.47 (s, 1H, 5-H), 7.62 (d, 1H, 6'-H), 7.73 (s, 1H, 2'-H), 8.26 (s, 1H, 4-H). Anal. $\mathrm{C}_{20} \mathrm{H}_{16} \mathrm{O}_{5} \mathrm{NCl}(\mathrm{C}, \mathrm{H}, \mathrm{N})$.

\subsubsection{N-Methyl-N-(4-chlorophenyl)-6-acetoxymethyl-2-oxo-2H-1-benzopyran-3 -carboxamide (16c)}

The title compound was obtained as described in the general procedure after the reaction of the acyl chloride of 6-acetoxymethyl-2-oxo-2H-1-benzopyran-3-carboxylic acid (13) ( 3.8 mmol) with 4-chloro- $N$-methylaniline $(0.7 \mathrm{~g}, 5 \mathrm{mmol})$ and pyridine $(1 \mathrm{~mL}, 12.5 \mathrm{mmol})$. After $6 \mathrm{~h}$ at room temperature, water was added and the mixture was cooled on an ice bath, then the resulting precipitate was collected by filtration and dried. The crude product was crystallized in methanol: $\mathrm{mp} 117-119^{\circ} \mathrm{C}$; IR 3054, $2951(\mathrm{C}-\mathrm{H}$ arom $), 1744(\mathrm{C}=\mathrm{O}$ ester $), 1731(\mathrm{C}=\mathrm{O}$ lactone), $1649\left(\mathrm{C}=\mathrm{O}\right.$ amide), 1622, 1580, 1494, $1224 \mathrm{~cm}^{-1} ;{ }^{1} \mathrm{H}$ NMR $2.06\left(\mathrm{~s}, 3 \mathrm{H}, \mathrm{CH}_{3}\right), 3.33\left(\mathrm{~s}, 3 \mathrm{H}, \mathrm{NCH}_{3}\right), 5.11$ (s, 2H, $\mathrm{CH}_{2}$ ), 7.32-7.37 (m, 5H, 3'-H, 5'-H, 5-H, 7-H, 8-H), 7.62 (d, 1H, 6'-H), 7.71 (s, 1H, 2'-H), 8.24 (s, 1H, 4H). Anal. $\mathrm{C}_{20} \mathrm{H}_{16} \mathrm{O}_{5} \mathrm{NCl}(\mathrm{C}, \mathrm{H}, \mathrm{N})$.

\subsubsection{3-Bromophenyl 6-propionoxymethyl-2-oxo-2H-1-benzopyran-3-carboxylate (19a)}

The title compound was obtained as described in the general procedure after the reaction of the acyl chloride of 6-propionoxymethyl-2-oxo-2H-1-benzopyran-3-carboxylic acid (18a) ( 3.5mmol) with 3-bromophenol (0.71 g, $4 \mathrm{mmol})$ and pyridine $(0.4 \mathrm{~mL}, 5 \mathrm{mmol})$. After $12 \mathrm{~h}$ at room temperature, the solvent was removed by evaporation under reduced pressure. The residue was dissolved in $\mathrm{CHCl}_{3}$ and the organic layer was washed three times with $0.1 \mathrm{~N} \mathrm{HCl}$, then dried over $\mathrm{MgSO}_{4}$, filtered, and evaporated to dryness under reduced pressure. The residue was then dissolved in warm methanol, treated with charcoal and crystallized by cooling on an ice bath. The resulting precipitate was collected by filtration and dried: $\mathrm{mp} 124-124.5^{\circ} \mathrm{C}$; IR $3064(\mathrm{C}-\mathrm{H}$ arom $), 1775$ and $1737(\mathrm{C}=\mathrm{O}$ esters $), 1690(\mathrm{C}=\mathrm{O}$ lactone $), 1624,1577,1470,1377,1246 \mathrm{~cm}^{-1} ;{ }^{1} \mathrm{H}$ NMR 1.07 (t, 3H, $\left.\mathrm{CH}_{3}\right), 2.41(\mathrm{q}$, $\left.2 \mathrm{H}, \mathrm{CH}_{2} \mathrm{CH}_{3}\right), 5.19\left(\mathrm{~s}, 2 \mathrm{H}, \mathrm{CH}_{2} \mathrm{OCOC}_{2} \mathrm{H}_{5}\right), 7.33\left(\mathrm{~d}, 1 \mathrm{H}, 66^{\prime}-\mathrm{H}\right), 7.46(\mathrm{t}, 1 \mathrm{H}, 5$ '- $\mathrm{H}), 7.50(\mathrm{~d}, 1 \mathrm{H}, 8-\mathrm{H}), 7.55(\mathrm{~d}, 1 \mathrm{H}$, 4'-H), 7.60 (s, 1H, 2'-H), 7.88 (d, 1H, 7-H), 7.97 (s, 1H, 5-H), 9.09 (s, 1H, 4-H). Anal. $\mathrm{C}_{20} \mathrm{H}_{15} \mathrm{BrO}_{6}(\mathrm{C}, \mathrm{H})$. 


\subsubsection{3-Bromophenyl 6-butyryloxymethyl-2-oxo-2H-1-benzopyran-3-carboxylate (19b)}

The title compound was obtained as described in the general procedure after the reaction of the acyl chloride of 6-butyryloxymethyl-2-oxo-2H-1-benzopyran-3-carboxylic acid (18b) ( 3.3 mmol) with 3-bromophenol (0.7 g, 4 $\mathrm{mmol})$ and pyridine $(0.4 \mathrm{~mL}, 5 \mathrm{mmol})$. After $12 \mathrm{~h}$ at room temperature, the solvent was removed by evaporation under reduced pressure. The residue was dissolved in $\mathrm{CHCl}_{3}$ and the organic layer was washed three times with $0.1 \mathrm{~N} \mathrm{HCl}$, then dried over $\mathrm{MgSO}_{4}$, filtered, and evaporated to dryness under reduced pressure. The residue was then dissolved in warm methanol, treated with charcoal and crystallized by cooling on an ice bath. The resulting precipitate was collected by filtration and dried: $\mathrm{mp} 140.5^{\circ} \mathrm{C}$; IR $3067(\mathrm{C}-\mathrm{H}$ arom $), 1736(\mathrm{C}=\mathrm{O}$ esters $), 1691$ $\left(\mathrm{C}=\mathrm{O}\right.$ lactone), 1628, 1579, 1471, 1367, $1247 \mathrm{~cm}^{-1}$; ${ }^{1} \mathrm{H}$ NMR $0.89\left(\mathrm{t}, 3 \mathrm{H}, \mathrm{CH}_{3}\right), 1.58\left(\mathrm{~m}, 2 \mathrm{H}, \mathrm{CH}_{2} \mathrm{CH}_{3}\right), 2.37(\mathrm{t}$, $\left.2 \mathrm{H}, \mathrm{CH}_{2} \mathrm{CH}_{2} \mathrm{CH}_{3}\right), 5.19$ (s, 2H, CH $\left.\mathrm{CHC}_{2} \mathrm{O}\left(\mathrm{CH}_{2}\right)_{2} \mathrm{CH}_{3}\right), 7.33\left(\mathrm{~d}, 1 \mathrm{H}, 66^{\prime}-\mathrm{H}\right), 7.47\left(\mathrm{t}, 1 \mathrm{H}, 5^{\prime}-\mathrm{H}\right), 7.50(\mathrm{~d}, 1 \mathrm{H}, 8-\mathrm{H})$, $7.55\left(\mathrm{~d}, 1 \mathrm{H}, 4\right.$ '-H), $7.60\left(\mathrm{~s}, 1 \mathrm{H}, 2^{\prime}-\mathrm{H}\right), 7.78(\mathrm{~d}, 1 \mathrm{H}, 7-\mathrm{H}), 7.97(\mathrm{~s}, 1 \mathrm{H}, 5-\mathrm{H}), 9.09(\mathrm{~s}, 1 \mathrm{H}, 4-\mathrm{H})$. Anal. $_{21} \mathrm{H}_{17} \mathrm{BrO}_{6}$ (C, H).

\subsubsection{3-Bromophenyl 6-valeryloxymethyl-2-oxo-2H-1-benzopyran-3-carboxylate (19c)}

The title compound was obtained as described in the general procedure after the reaction of the acyl chloride of 6-valeryloxymethyl-2-oxo-2H-1-benzopyran-3-carboxylic acid (18c) $(\sim 3.1 \mathrm{mmol})$ with 3-bromophenol $(0.65 \mathrm{~g}$, $3.7 \mathrm{mmol})$ and pyridine $(0.4 \mathrm{~mL}, 5 \mathrm{mmol})$. After $12 \mathrm{~h}$ at room temperature, the solvent was removed by evaporation under reduced pressure. The residue was dissolved in $\mathrm{CHCl}_{3}$ and the organic layer was washed three times with $0.1 \mathrm{~N} \mathrm{HCl}$, then dried over $\mathrm{MgSO}_{4}$, filtered, and evaporated to dryness under reduced pressure. The residue was then dissolved in warm methanol, treated with charcoal and crystallized by cooling on ice bath. The resulting precipitate was collected by filtration and dried: $\mathrm{mp} 133-134.5^{\circ} \mathrm{C}$; IR $3066(\mathrm{C}-\mathrm{H}$ arom $), 1736(\mathrm{C}=\mathrm{O}$ esters), $1690\left(\mathrm{C}=\mathrm{O}\right.$ lactone), 1628, 1579, 1471, 1367, $1247 \mathrm{~cm}^{-1} ;{ }^{1} \mathrm{H}$ NMR 0.87 (t, 3H, $\left.\mathrm{CH}_{3}\right), 1.30(\mathrm{~m}, 2 \mathrm{H}$, $\left.\mathrm{CH}_{2} \mathrm{CH}_{3}\right), 1.54\left(\mathrm{~m}, 2 \mathrm{H}, \mathrm{CH}_{2} \mathrm{CH}_{2} \mathrm{CH}_{3}\right), 2.38\left(\mathrm{t}, 2 \mathrm{H}, \mathrm{CH}_{2} \mathrm{CH}_{2} \mathrm{CH}_{2} \mathrm{CH}_{3}\right), 5.18\left(\mathrm{~s}, 2 \mathrm{H}, \mathrm{CH}_{2} \mathrm{OCO}\left(\mathrm{CH}_{2}\right)_{3} \mathrm{CH}_{3}\right), 7.33(\mathrm{~d}$, $\left.1 \mathrm{H}, 66^{\prime}-\mathrm{H}\right), 7.47\left(\mathrm{t}, 1 \mathrm{H}, 5^{\prime}-\mathrm{H}\right), 7.50(\mathrm{~d}, 1 \mathrm{H}, 8-\mathrm{H}), 7.55\left(\mathrm{~d}, 1 \mathrm{H}, 4^{\prime}-\mathrm{H}\right), 7.56\left(\mathrm{~s}, 1 \mathrm{H}, 2^{\prime}-\mathrm{H}\right), 7.78(\mathrm{~d}, 1 \mathrm{H}, 7-\mathrm{H}), 7.97$ (s, $1 \mathrm{H}, 5-\mathrm{H}), 9.09(\mathrm{~s}, 1 \mathrm{H}, 4-\mathrm{H})$. Anal. $\mathrm{C}_{22} \mathrm{H}_{19} \mathrm{BrO}_{6}(\mathrm{C}, \mathrm{H})$.

\subsubsection{3-Bromophenyl 6-hexanoyloxymethyl-2-oxo-2H-1-benzopyran-3-carboxylate (19d)}

The title compound was obtained as described in the general procedure after the reaction of the acyl chloride of 6-hexanoyloxymethyl-2-oxo-2H-1-benzopyran-3-carboxylic acid (18d) ( 3 mmol) with 3-bromophenol ( $0.6 \mathrm{~g}$, $3.5 \mathrm{mmol})$ and pyridine $(0.4 \mathrm{~mL}, 5 \mathrm{mmol})$. After $12 \mathrm{~h}$ at room temperature, the solvent was removed by evaporation under reduced pressure. The residue was dissolved in $\mathrm{CHCl}_{3}$ and the organic layer was washed three times with $0.1 \mathrm{~N} \mathrm{HCl}$, then dried over $\mathrm{MgSO}_{4}$, filtered, and evaporated to dryness under reduced pressure. The residue was then dissolved in warm methanol, treated with charcoal and crystallized by cooling on an ice bath. The resulting precipitate was collected by filtration and dried: $\mathrm{mp} 122.5-126^{\circ} \mathrm{C}$; IR 3067 (C-H arom), 1732 $(\mathrm{C}=\mathrm{O}$ esters $), 1692(\mathrm{C}=\mathrm{O}$ lactone $), 1628,1580,1471,1367,1247 \mathrm{~cm}^{-1} ;{ }^{1} \mathrm{H}$ NMR 0.85 (t, 3H, $\left.\mathrm{CH}_{3}\right), 1.26(\mathrm{~m}, 4 \mathrm{H}$, $\left.\mathrm{CH}_{2} \mathrm{CH}_{2} \mathrm{CH}_{3}\right), 1.56\left(\mathrm{~m}, 2 \mathrm{H}, \mathrm{CH}_{2}\left(\mathrm{CH}_{2}\right)_{2} \mathrm{CH}_{3}\right), 2.38\left(\mathrm{t}, 2 \mathrm{H}, \mathrm{CH}_{2}\left(\mathrm{CH}_{2}\right)_{3} \mathrm{CH}_{3}\right), 5.18\left(\mathrm{~s}, 2 \mathrm{H}, \mathrm{CH}_{2} \mathrm{OCO}\left(\mathrm{CH}_{2}\right)_{4} \mathrm{CH}_{3}\right)$, 7.32 (d, 1H, 6'-H), 7.51 (t, 1H, 5'-H), 7.54 (d, 1H, 8-H), 7.56 (d, 1H, 4'-H), 7.60 (s, 1H, 2'-H), 7.78 (d, 1H, 7-H), 7.97 (s, 1H, 5-H), 9.09 (s, 1H, 4-H). Anal. $\mathrm{C}_{23} \mathrm{H}_{21} \mathrm{BrO}_{6}(\mathrm{C}, \mathrm{H})$.

\subsubsection{3-Bromophenyl 6-heptanoyloxymethyl-2-oxo-2H-1-benzopyran-3-carboxylate (19e)}

The title compound was obtained as described in the general procedure after the reaction of the acyl chloride of 6-heptanoyloxymethyl-2-oxo-2H-1-benzopyran-3-carboxylic acid (18e) ( 2.9 mmol) with 3-bromophenol (0.6 g, $3.5 \mathrm{mmol})$ and pyridine $(0.4 \mathrm{~mL}, 5 \mathrm{mmol})$. After $12 \mathrm{~h}$ at room temperature, the solvent was removed by evaporation under reduced pressure. The residue was dissolved in $\mathrm{CHCl}_{3}$ and the organic layer was washed three times with $0.1 \mathrm{~N} \mathrm{HCl}$, then dried over $\mathrm{MgSO}_{4}$, filtered, and evaporated to dryness under reduced pressure. The residue was then dissolved in warm methanol, treated with charcoal and crystallized by cooling on an ice bath. The resulting precipitate was collected by filtration and dried: $\mathrm{mp} 121-122.5^{\circ} \mathrm{C}$; IR 3067 (C-H arom), 1734 $(\mathrm{C}=\mathrm{O}$ esters $), 1689$ (C=O lactone), 1628, 1580, 1471, 1367, $1247 \mathrm{~cm}^{-1} ;{ }^{1} \mathrm{H}$ NMR 0.84 (t, 3H, $\left.\mathrm{CH}_{3}\right), 1.24$ (m, 6H, $\left.\left(\mathrm{CH}_{2}\right)_{3} \mathrm{CH}_{3}\right), 1.55\left(\mathrm{~m}, 2 \mathrm{H}, \mathrm{CH}_{2}\left(\mathrm{CH}_{2}\right)_{3} \mathrm{CH}_{3}\right), 2.38\left(\mathrm{t}, 2 \mathrm{H}, \mathrm{CH}_{2}\left(\mathrm{CH}_{2}\right)_{4} \mathrm{CH}_{3}\right), 5.18(\mathrm{~s}, 2 \mathrm{H}$, $\left.\mathrm{CH}_{2} \mathrm{OCO}\left(\mathrm{CH}_{2}\right)_{5} \mathrm{CH}_{3}\right), 7.33\left(\mathrm{~d}, 1 \mathrm{H}, 66^{\prime}-\mathrm{H}\right), 7.47\left(\mathrm{t}, 1 \mathrm{H}, 5^{\prime}-\mathrm{H}\right), 7.50(\mathrm{~d}, 1 \mathrm{H}, 8-\mathrm{H}), 7.56\left(\mathrm{~d}, 1 \mathrm{H}, 4{ }^{\prime}-\mathrm{H}\right), 7.60\left(\mathrm{~s}, 1 \mathrm{H}, 2^{\prime}-\right.$ H), 7.78 (d, 1H, 7-H), 7.97 (s, 1H, 5-H), 9.09 (s, 1H, 4-H). Anal. $\mathrm{C}_{24} \mathrm{H}_{23} \mathrm{BrO}_{6}(\mathrm{C}, \mathrm{H})$.

\subsubsection{3-Bromophenyl 6-dimethylacetoxymethyl-2-oxo-2H-1-benzopyran-3-carboxylate (19f)}

The title compound was obtained as described in the general procedure after the reaction of the acyl chloride of 6-dimethylacetoxymethyl-2-oxo-2H-1-benzopyran-3-carboxylic acid (18f) ( $\sim 3.3 \mathrm{mmol})$ with 3-bromophenol $(0.69 \mathrm{~g}, 4 \mathrm{mmol})$ and pyridine $(0.4 \mathrm{~mL}, 5 \mathrm{mmol})$. After $12 \mathrm{~h}$ at room temperature, the solvent was removed by evaporation under reduced pressure. The residue was dissolved in $\mathrm{CHCl}_{3}$ and the organic layer was washed three times with $0.1 \mathrm{~N} \mathrm{HCl}$, then dried over $\mathrm{MgSO}_{4}$, filtered, and evaporated to dryness under reduced pressure. The residue was then dissolved in warm methanol, treated with charcoal and crystallized by cooling on an ice bath. The resulting precipitate was collected by filtration and dried: $\mathrm{mp} 152-153^{\circ} \mathrm{C}$; IR 3067 (C-H arom), 1735 (C=O 
esters and lactone), 1628, 1579, 1472, 1368, $1247 \mathrm{~cm}^{-1} ;{ }^{1} \mathrm{H}$ NMR $1.12\left(\mathrm{~d}, 6 \mathrm{H}, \mathrm{CH}_{3}\right), 2.63(\mathrm{q}, 1 \mathrm{H}, \mathrm{CH}), 5.18(\mathrm{~s}$, $\left.2 \mathrm{H}, \mathrm{CH}_{2} \mathrm{OCOCH}\left(\mathrm{CH}_{3}\right)_{2}\right), 7.33\left(\mathrm{~d}, 1 \mathrm{H}, 66^{\prime}-\mathrm{H}\right), 7.46(\mathrm{t}, 1 \mathrm{H}, 5$ '-H), $7.50(\mathrm{~d}, 1 \mathrm{H}, 8-\mathrm{H}), 7.54(\mathrm{~d}, 1 \mathrm{H}, 4$ '- $\mathrm{H}), 7.60$ (s, $\left.1 \mathrm{H}, 2^{\prime}-\mathrm{H}\right), 7.78(\mathrm{~d}, 1 \mathrm{H}, 7-\mathrm{H}), 7.97(\mathrm{~s}, 1 \mathrm{H}, 5-\mathrm{H}), 9.10$ (s, 1H, 4-H). Anal. $\mathrm{C}_{21} \mathrm{H}_{17} \mathrm{BrO}_{6}(\mathrm{C}, \mathrm{H})$.

\subsubsection{3-Bromophenyl 6-trimethylacetoxymethyl-2-oxo-2H-1-benzopyran-3-carboxylate (19g)}

The title compound was obtained as described in the general procedure after the reaction of the acyl chloride of 6-trimethylacetoxymethyl-2-oxo-2H-1-benzopyran-3-carboxylic acid (18g) $(\sim 3.1 \mathrm{mmol})$ with 3-bromophenol $(0.6 \mathrm{~g}, 3.5 \mathrm{mmol})$ and pyridine $(0.4 \mathrm{~mL}, 5 \mathrm{mmol})$. After $12 \mathrm{~h}$ at room temperature, the solvent was removed by evaporation under reduced pressure. The residue was dissolved in $\mathrm{CHCl}_{3}$ and the organic layer was washed three times with $0.1 \mathrm{~N} \mathrm{HCl}$, then dried over $\mathrm{MgSO}_{4}$ filtered, and evaporated to dryness under reduced pressure. The residue was then dissolved in warm methanol, treated with charcoal and crystallized by cooling on an ice bath. The resulting precipitate was collected by filtration and dried: $\mathrm{mp} 158-161^{\circ} \mathrm{C}$; IR $3067(\mathrm{C}-\mathrm{H}$ arom $), 1732(\mathrm{C}=\mathrm{O}$ esters), 1686 (C=O lactone), 1628, 1580, 1471, 1367, $1247 \mathrm{~cm}^{-1} ;{ }^{1} \mathrm{H}$ NMR 1.22 (s, 9H, $\left.\mathrm{CH}_{3}\right), 5.18$ (s, 2H, $\left.\mathrm{CH}_{2} \mathrm{OCOC}\left(\mathrm{CH}_{3}\right)_{3}\right), 7.33$ (d, 1H, 6'-H), 7.47 (t, 1H, 5'-H), 7.51 (d, 1H, 8-H), 7.55 (d, 1H, 4'-H), 7.60 (s, 1H, 2'H), $7.78(\mathrm{~d}, 1 \mathrm{H}, 7-\mathrm{H}), 7.97(\mathrm{~s}, 1 \mathrm{H}, 5-\mathrm{H}), 9.12(\mathrm{~s}, 1 \mathrm{H}, 4-\mathrm{H})$. Anal. $\mathrm{C}_{22} \mathrm{H}_{19} \mathrm{BrO}_{6}(\mathrm{C}, \mathrm{H})$.

\subsubsection{Phenyl 6-nitro-2-oxo-2H-1-benzopyran-3-carboxylate (24a)}

The title compound was obtained as described in the general procedure after the reaction of the acyl chloride of 6-nitro-2-oxo-2H-1-benzopyran-3-carboxylic acid (23) ( $\sim 4 \mathrm{mmol})$ with phenol $(0.85 \mathrm{~g}, 9 \mathrm{mmol})$ and pyridine (1 $\mathrm{mL}, 12.5 \mathrm{mmol}$ ). After $8 \mathrm{~h}$ at room temperature, the resulting precipitate was collected by filtration, washed with dioxane and left overnight at $30^{\circ} \mathrm{C}$. The crude product was stirred in methanol and collected by filtration. It was then dissolved in warm DMF, treated with charcoal and filtered. The filtrate was kept at $4^{\circ} \mathrm{C}$ for $2 \mathrm{~h}$. The resulting precipitate was collected, washed with DMF and methanol and dried for one night at $30^{\circ} \mathrm{C}$. The crude product was suspended in methanol and collected by filtration (precipitate 1). Methanol was added to DMF filtrate and the resulting precipitate was collected by filtration, washed with methanol and pooled with precipitate 1: $\mathrm{mp}$ 236.5-237. $5^{\circ} \mathrm{C}$; IR 3070 (C-H arom), 1775 (C=O ester), 1722 (C=O lactone), 1618, 1573, 1539, 1345, $1256 \mathrm{~cm}^{-1}$; ${ }^{1} \mathrm{H}$ NMR 7.28-7.36 (m, 3H, 2'-H, 4'-H, 6'-H), 7.49-7.52 (m, 2H, 3'-H, 5'-H), 7.71 (d, 1H, 8-H), 8.56 $(\mathrm{d}, 1 \mathrm{H}, 7-\mathrm{H}), 8.99(\mathrm{~s}, 1 \mathrm{H}, 5-\mathrm{H}), 9.25(\mathrm{~s}, 1 \mathrm{H}, 4-\mathrm{H})$. Anal. $\mathrm{C}_{16} \mathrm{H}_{9} \mathrm{NO}_{6}(\mathrm{C}, \mathrm{H}, \mathrm{N})$.

\subsubsection{3-Fluorophenyl 6-nitro-2-oxo-2H-1-benzopyran-3-carboxylate (24b)}

The title compound was obtained as described in the general procedure after the reaction of the acyl chloride of 6-nitro-2-oxo-2H-1-benzopyran-3-carboxylic acid (23) ( 4mmol) with 3-fluorophenol (1 g, $9 \mathrm{mmol})$ and pyridine $(1 \mathrm{~mL}, 12.5 \mathrm{mmol})$. After $8 \mathrm{~h}$ at room temperature, the resulting precipitate was collected by filtration, washed with dioxane and kept overnight at $30^{\circ} \mathrm{C}$. The crude product was stirred in methanol and collected by filtration. It was then dissolved in warm DMF, treated with charcoal and filtered. The filtrate was kept at $4^{\circ} \mathrm{C}$ for $2 \mathrm{~h}$. The resulting precipitate was collected by filtration, washed with DMF and methanol and dried for one night at $30^{\circ} \mathrm{C}$. The crude product was suspended in methanol and collected by filtration (precipitate 1). Methanol was added to DMF filtrate and the resulting precipitate was collected by filtration, washed with methanol and pooled with precipitate $1: \mathrm{mp} 226-226.5^{\circ} \mathrm{C}$; IR 3086 (C-H arom), 1779 (C=O ester), 1721 (C=O lactone), 1621, 1572 , 1532, 1346, $1248 \mathrm{~cm}^{-1}$; ${ }^{1} \mathrm{H}$ NMR 7.16-7.28 (m, 3H, 2'-H, 4'-H, 6'-H), 7.55 (t, 1H, 5'-H), 7.72 (d, 1H, 8-H), 8.56 (d, 1H, 7-H), 8.99 (s, 1H, 5-H), 9.28 (s, 1H, 4-H). Anal. $\mathrm{C}_{16} \mathrm{H}_{8} \mathrm{NO}_{6} \mathrm{~F}(\mathrm{C}, \mathrm{H}, \mathrm{N})$.

\subsubsection{3-Chlorophenyl 6-nitro-2-oxo-2H-1-benzopyran-3-carboxylate (24c)}

The title compound was obtained as described in the general procedure after the reaction of the acyl chloride of 6-nitro-2-oxo-2H-1-benzopyran-3-carboxylic acid (23) ( 4mmol) with 3-chlorophenol (1.15 g, 9 mmol) and pyridine $(1 \mathrm{~mL}, 12.5 \mathrm{mmol})$. After $8 \mathrm{~h}$ at room temperature, the resulting precipitate was collected by filtration, washed with dioxane and left overnight at $30^{\circ} \mathrm{C}$. The crude product was stirred in methanol and collected by filtration. It was then dissolved in warm acetone $(\sim 150 \mathrm{~mL})$, treated with charcoal and filtered. The filtrate was kept at $4^{\circ} \mathrm{C}$ for $2 \mathrm{~h}$ and the resulting precipitate was collected by filtration, washed with cold acetone and dried: mp 245.5-246 ${ }^{\circ} \mathrm{C}$; IR $3075(\mathrm{C}-\mathrm{H}$ arom $), 1770(\mathrm{C}=\mathrm{O}$ ester $), 1723(\mathrm{C}=\mathrm{O}$ lactone $), 1620,1572,1541,1347,1248$ $\mathrm{cm}^{-1}$; ${ }^{1} \mathrm{H}$ NMR 7.31 (d, 1H, 6'-H), 7.45 (d, 1H, 4'-H), 7.48 (s, 1H, 2'-H), 7.55 (t, 1H, 5'-H), 7.72 (d, 1H, 8-H), 8.57 (d, 1H, 7-H), 8.99 (s, 1H, 5-H), 9.27 (s, 1H, 4-H). Anal. $\mathrm{C}_{16} \mathrm{H}_{8} \mathrm{NO}_{6} \mathrm{C} 1(\mathrm{C}, \mathrm{H}, \mathrm{N})$.

\subsubsection{3-Bromophenyl 6-nitro-2-oxo-2H-1-benzopyran-3-carboxylate (24d)}

The title compound was obtained as described in the general procedure after the reaction of the acyl chloride of 6-nitro-2-oxo-2H-1 -benzopyran-3-carboxylic acid (23) ( 4 mmol) with 3-bromophenol (1.56 g, $9 \mathrm{mmol})$ and pyridine $(1 \mathrm{~mL}, 12.5 \mathrm{mmol})$. After $4 \mathrm{~h}$ at room temperature, the resulting precipitate was collected by filtration, washed with dioxane and kept overnight at $30^{\circ} \mathrm{C}$. The crude product was stirred in methanol and collected by filtration. It was then dissolved in warm DMF, treated with charcoal and filtered. The filtrate was kept at $4^{\circ} \mathrm{C}$ for $2 \mathrm{~h}$. The resulting precipitate was collected by filtration, washed with cold DMF and dried for one night at $30^{\circ} \mathrm{C}$. 
The crude product was dissolved in warm dioxane and treated with charcoal. The filtrate was cooled and the resulting precipitate was collected by filtration, washed with dioxane and water: $\mathrm{mp} 268-270{ }^{\circ} \mathrm{C}$; IR $3070(\mathrm{C}-\mathrm{H}$ arom), $1772\left(\mathrm{C}=\mathrm{O}\right.$ ester), $1719(\mathrm{C}=\mathrm{O}$ lactone $), 1618,1572,1537,1346,1248 \mathrm{~cm}^{-1}$; ${ }^{1} \mathrm{H}$ NMR $7.34\left(\mathrm{~d}, 1 \mathrm{H}, 6^{\prime}-\mathrm{H}\right)$, 7.48 (t, 1H, 5'-H), 7.57 (d, 1H, 4'-H), 7.61 (s, 1H, 2'-H), 7.71 (d, 1H, 8-H), 8.57 (d, 1H, 7-H), 8.98 (d, 1H, 5-H), $9.26(\mathrm{~s}, 1 \mathrm{H}, 4-\mathrm{H})$. Anal. $\mathrm{C}_{16} \mathrm{H}_{8} \mathrm{NO}_{6} \mathrm{Br}(\mathrm{C}, \mathrm{H}, \mathrm{N})$.

\subsubsection{3-Iodophenyl 6-nitro-2-oxo-2H-1-benzopyran-3-carboxylate (24e)}

The title compound was obtained as described in the general procedure after the reaction of the acyl chloride of 6-nitro-2-oxo-2H-1-benzopyran-3-carboxylic acid (23) ( 4 mmol) with 3-iodophenol (1.98 g, $9 \mathrm{mmol})$ and pyridine $(1 \mathrm{~mL}, 12.5 \mathrm{mmol})$. After $8 \mathrm{~h}$ at room temperature, the resulting precipitate was collected by filtration, washed with dioxane and kept overnight at $30^{\circ} \mathrm{C}$. The crude product was stirred in methanol and collected by filtration. It was then dissolved in warm DMF, treated with charcoal and filtered. The filtrate was kept at $4{ }^{\circ} \mathrm{C}$ for $2 \mathrm{~h}$. The resulting precipitate was collected by filtration, washed with DMF and methanol and dried for one night at $30^{\circ} \mathrm{C}$ : $\mathrm{mp}>260^{\circ} \mathrm{C}$; IR $3068(\mathrm{C}-\mathrm{H}$ arom $), 1770(\mathrm{C}=\mathrm{O}$ ester $), 1720(\mathrm{C}=\mathrm{O}$ lactone $), 1616,1570,1532,1344$, $1247 \mathrm{~cm}^{-1}$; ${ }^{1} \mathrm{H}$ NMR 7.32 (d, 1H, 6'-H), 7.45 (t, 1H, 5'-H), 7.58 (d, 1H, 4'-H), 7.60 (s, 1H, 2'-H), 7.71 (d, $1 \mathrm{H}, 8-$ $\mathrm{H}), 8.57(\mathrm{~d}, 1 \mathrm{H}, 7-\mathrm{H}), 8.98(\mathrm{~d}, 1 \mathrm{H}, 5-\mathrm{H}), 9.28(\mathrm{~s}, 1 \mathrm{H}, 4-\mathrm{H})$. Anal. $\mathrm{C}_{16} \mathrm{H}_{8} \mathrm{NO}_{6} \mathrm{I}(\mathrm{C}, \mathrm{H}, \mathrm{N})$.

\subsubsection{Phenyl 6-aminomethyl-2-oxo-2H-1-benzopyran-3-carboxylate chloride salt (27a)}

Hexamethylenetetramine $(1.55 \mathrm{~g}, 11 \mathrm{mmol})$ was added to a solution of phenyl 6-chloromethyl-2-oxo-2H-1benzopyran-3-carboxylate (25a) $(1.5 \mathrm{~g}, 3.2 \mathrm{mmol})$ in $\mathrm{CHCl}_{3}(45 \mathrm{~mL})$. The mixture was heated under reflux for $18 \mathrm{~h}$. The resulting precipitate of phenyl 6-hexamethylenetetrammoniomethyl-2-oxo- $\mathrm{H}$-1-benzopyran-3carboxylate chloride salt (26a) was collected by filtration and washed with warm $\mathrm{CHCl}_{3}$ (yield: $92 \%$ ): $\mathrm{mp} 169$ $171^{\circ} \mathrm{C}$. Phenyl 6-hexamethylenetetrammoniomethyl-2-oxo- $2 H$-1-benzopyran-3-carboxylate chloride salt (26a) $(2.2 \mathrm{~g}, 4.8 \mathrm{mmol})$ and $12 \mathrm{~N} \mathrm{HCl}(3.8 \mathrm{~mL})$ in ethanol $(16 \mathrm{~mL})$ were heated under reflux for $90 \mathrm{~min}$. After cooling, the resulting precipitate was collected by filtration, washed with ethanol and discarded. The filtrate was evaporated to dryness under reduced pressure and the residue was suspended in a $1 \%$ aqueous solution of $\mathrm{NaHCO}_{3}$. The resulting precipitate was collected by filtration and washed with water: $\mathrm{mp}>260^{\circ} \mathrm{C}$; IR $3067(\mathrm{C}-\mathrm{H}$ arom), $2885\left(\mathrm{~N}^{+}-\mathrm{H}\right), 1775(\mathrm{C}=\mathrm{O}$ ester $), 1728(\mathrm{C}=\mathrm{O}$ lactone $), 1624,1576,1463,1371,1256,1203 \mathrm{~cm}^{-1}$; ${ }^{1} \mathrm{H}$ NMR 3.39 (b, 3H, $\left.\mathrm{NH}_{3}^{+}\right), 4.13$ (s, 2H, CH ), 7.20-7.26 (m, 3H, 2'-H, 4'-H, 6'-H), 7.50-7.57 (m, 3H, 5'-H, 6'-H, 8-H), $7.92(\mathrm{~d}, 1 \mathrm{H}, 7-\mathrm{H}), 7.99$ (d, 1H, 5-H), $9.01(\mathrm{~s}, 1 \mathrm{H}, 4-\mathrm{H})$. Anal. $\mathrm{C}_{17} \mathrm{H}_{13} \mathrm{NO}_{4} \cdot \mathrm{HCl}(\mathrm{C}, \mathrm{H}, \mathrm{N})$.

\subsubsection{3-Fluorophenyl 6-aminomethyl-2-oxo-2H-1-benzopyran-3-carboxylate chloride salt (27b)}

3-Fluorophenyl 6-hexamethylenetetrammoniomethyl-2-oxo-2H-1-benzopyran-3-carboxylate chloride salt (26b) was obtained as described for 26a after the reaction of hexamethylenetetramine $(1.15 \mathrm{~g}, 8.2 \mathrm{mmol})$ with 3fluorophenyl 6-chloromethyl-2-oxo-2H-1-benzopyran-3-carboxylate (25b) (1.2 g, $3.6 \mathrm{mmol}$ ). The resulting precipitate was collected by filtration and washed with cold $\mathrm{CHCl}_{3}$ (yield: $65 \%$ ): $\mathrm{mp} 182^{\circ} \mathrm{C}$. 3-fluorophenyl 6hexamethylenetetrammoniomethyl-2-oxo-2 $\mathrm{H}$-1-benzopyran-3-carboxylate chloride salt (26b) (1.6 g, $3.4 \mathrm{mmol})$ and $12 \mathrm{~N} \mathrm{HCl}(2.7 \mathrm{~mL})$ in ethanol $(11 \mathrm{~mL})$ were heated under reflux for $90 \mathrm{~min}$. After cooling, the resulting precipitate was collected by filtration and washed with ethanol. The crude product was suspended in water (elimination of $\mathrm{NH}_{4} \mathrm{Cl}$ ) and the resulting precipitate was collected by filtration and washed with water: $\mathrm{mp}$ $>260^{\circ} \mathrm{C}$; IR 2963; $2876\left(\mathrm{~N}^{+}-\mathrm{H}\right), 1779\left(\mathrm{C}=\mathrm{O}\right.$ esters), $1722\left(\mathrm{C}=\mathrm{O}\right.$ lactone), 1626, 1580, 1485, 1376, $1248 \mathrm{~cm}^{-1} ;{ }^{1} \mathrm{H}$ NMR 3.37 (b, 3H, $\left.\mathrm{NH}_{3}{ }^{+}\right), 4.12$ (s, 2H, $\left.\mathrm{CH}_{2}\right), 7.19-7.28$ (m, 3H, 2'-H, 4'-H, 6'-H), 7.52-7.59 (m, 2H, 5'-H, 8-H), $7.94(\mathrm{~d}, 1 \mathrm{H}, 7-\mathrm{H}), 8.04(\mathrm{~d}, 1 \mathrm{H}, 5-\mathrm{H}), 9.03(\mathrm{~s}, 1 \mathrm{H}, 4-\mathrm{H})$. Anal. $\mathrm{C}_{17} \mathrm{H}_{12} \mathrm{NO}_{4} \mathrm{~F} \cdot \mathrm{HCl}(\mathrm{C}, \mathrm{H}, \mathrm{N})$.

\subsubsection{3-Chlorophenyl 6-aminomethyl-2-oxo-2H-1-benzopyran-3-carboxylate chloride salt (27c)}

3-Chlorophenyl 6-hexamethylenetetrammoniomethyl-2-oxo-2H-1-benzopyran-3-carboxylate chloride salt (26c) was obtained as described for $\mathbf{2 6 a}$ after the reaction of hexamethylenetetramine (1.8 g, $12.8 \mathrm{mmol})$ with 3chlorophenyl 6-chloromethyl-2-oxo-2H-1-benzopyran-3-carboxylate (25c) (2 g, $5.7 \mathrm{mmol})$. The resulting precipitate was collected by filtration and washed with cold $\mathrm{CHCl}_{3}: \mathrm{mp} 210^{\circ} \mathrm{C}$. The title compound was obtained as described for 27b after the reaction of 3-chlorophenyl 6-hexamethylenetetrammoniomethyl-2-oxo-2H-1benzopyran-3-carboxylate chloride salt (30c) $(2 \mathrm{~g}, 4 \mathrm{mmol})$ with $12 \mathrm{~N} \mathrm{HCl}(3.2 \mathrm{~mL})$ in ethanol $(13.3 \mathrm{~mL})($ yield: 40\%): $\mathrm{mp}>260^{\circ} \mathrm{C}$; IR 2987, $2882\left(\mathrm{~N}^{+}-\mathrm{H}\right), 1777(\mathrm{C}=\mathrm{O}$ esters $), 1720$ (C=O lactone), 1626, 1579, 1488, 1382, $1246 \mathrm{~cm}^{-1}$; ${ }^{1} \mathrm{H}$ NMR $3.33\left(\mathrm{~b}, 3 \mathrm{H}, \mathrm{NH}_{3}^{+}\right), 4.12\left(\mathrm{~s}, 2 \mathrm{H}, \mathrm{CH}_{2}\right), 7.30\left(\mathrm{~d}, 1 \mathrm{H}, 66^{\prime}-\mathrm{H}\right), 7.43\left(\mathrm{~d}, 1 \mathrm{H}, 4^{\prime}-\mathrm{H}\right), 7.48(\mathrm{~s}, 1 \mathrm{H}$, $\left.2^{\prime} \mathrm{H}\right), 7.52-7.59$ (m, 2H, 5'-H, 8-H), 7.95 (d, 1H, 7-H), 8.04 (d, 1H, 5-H), 9.03 (s, 1H, 4-H). Anal. $\mathrm{C}_{17} \mathrm{H}_{12} \mathrm{NO}_{4} \mathrm{Cl} \cdot \mathrm{HCl}(\mathrm{C}, \mathrm{H}, \mathrm{N})$.

\subsubsection{3-Bromophenyl 6-aminomethyl-2-oxo-2H-1-benzopyran-3-carboxylate chloride salt (27d)}

3-Bromophenyl 6-hexamethylenetetrammoniomethyl-2-oxo-2H-1-benzopyran-3-carboxylate chloride salt (26d) was obtained as described for 26a after the reaction of hexamethylenetetramine $(2.9 \mathrm{~g}, 20.7 \mathrm{mmol})$ with 3bromophenyl 6-chloromethyl-2-oxo-2H-1-benzopyran-3-carboxylate (25d) (4 g, $10 \mathrm{mmol})$. The resulting 
precipitate was collected by filtration and washed with cold $\mathrm{CHCl}_{3}: \mathrm{mp} 174-178^{\circ} \mathrm{C}$. The title compound was obtained as described for $\mathbf{2 7} \mathbf{b}$ after the reaction of 3-bromophenyl 6-hexamethylenetetrammoniomethyl-2-oxo2H-1-benzopyran-3-carboxylate chloride salt (26d) $(3 \mathrm{~g}, 5.6 \mathrm{mmol})$ with $12 \mathrm{~N} \mathrm{HCl}(4.5 \mathrm{~mL})$ in ethanol (18.7 mL) (yield: $65 \%): \mathrm{mp}>260^{\circ} \mathrm{C}$; IR 2986, $2885\left(\mathrm{~N}^{+}-\mathrm{H}\right), 1776(\mathrm{C}=\mathrm{O}$ esters), $1720(\mathrm{C}=\mathrm{O}$ lactone $), 1627$, 1580, 1469, 1381, $1246 \mathrm{~cm}^{-1}$; ${ }^{1} \mathrm{H}$ NMR $3.36\left(\mathrm{~b}, 3 \mathrm{H}, \mathrm{NH}_{3}^{+}\right), 4.13\left(\mathrm{~s}, 2 \mathrm{H}, \mathrm{CH}_{2}\right), 7.34\left(\mathrm{~d}, 1 \mathrm{H}, 66^{\prime}-\mathrm{H}\right), 7.47$ (t, $1 \mathrm{H}, 5^{\prime}-$ H), 7.55-7.61 (m, 3H, 2'-H, 4'-H, 8-H), 7.94 (d, 1H, 7-H), 8.03 (d, 1H, 5-H), 9.05 (s, 1H, 4-H). Anal. $\mathrm{C}_{17} \mathrm{H}_{12} \mathrm{NO}_{4} \mathrm{Br} \cdot \mathrm{HCl}(\mathrm{C}, \mathrm{H}, \mathrm{N})$.

\subsubsection{3-Iodophenyl 6-aminomethyl-2-oxo-2H-1-benzopyran-3-carboxylate chloride salt (27e)}

3-Iodophenyl 6-hexamethylenetetrammoniomethyl-2-oxo-2 $\mathrm{H}$-1-benzopyran-3-carboxylate chloride salt (26e) was obtained as described for 26a after the reaction of hexamethylenetetramine $(1 \mathrm{~g}, 7 \mathrm{mmol})$ with 3-iodophenyl 6-chloromethyl-2-oxo-2H-1-benzopyran-3-carboxylate (25e) (1.2 g, $2.7 \mathrm{mmol})$. The resulting precipitate was collected by filtration and washed with cold $\mathrm{CHCl}_{3}$ (yield: $70 \%$ ): $\mathrm{mp} 171-175^{\circ} \mathrm{C}$. The title compound was obtained as described for $\mathbf{2 7} \mathbf{b}$ after the reaction of 3-iodophenyl 6-hexamethylenetetrammoniomethyl-2-oxo- $2 \mathrm{H}$ 1-benzopyran-3-carboxylate chloride salt (26e) $(1.1 \mathrm{~g}, 1.9 \mathrm{mmol})$ with $12 \mathrm{~N} \mathrm{HCl}(1.5 \mathrm{~mL})$ in ethanol $(6.3 \mathrm{~mL})$ : $\mathrm{mp}>260^{\circ} \mathrm{C}$; IR 2987, $2890\left(\mathrm{~N}^{+}-\mathrm{H}\right), 1778(\mathrm{C}=\mathrm{O}$ esters $), 1722(\mathrm{C}=\mathrm{O}$ lactone $), 1627,1581,1466,1380,1245 \mathrm{~cm}^{-1}$; ${ }^{1} \mathrm{H}$ NMR 3.38 (b, 3H, NH$\left.{ }_{3}^{+}\right), 4.13$ (s, 2H, $\left.\mathrm{CH}_{2}\right), 7.28-7.34$ (m, 2H, 5'-H, 6'-H), 7.58 (d, 1H, 8-H), 7.70-7.74 (m, $\left.2 \mathrm{H}, 2^{\prime}-\mathrm{H}, 4^{\prime}-\mathrm{H}\right), 7.93$ (d, 1H, 7-H), 8.03 (d, 1H, 5-H), 9.02 (s, 1H, 4-H). Anal. $\mathrm{C}_{17} \mathrm{H}_{12} \mathrm{NO}_{4} \mathrm{I} \cdot \mathrm{HCl}(\mathrm{C}, \mathrm{H}, \mathrm{N})$.

\subsubsection{Phenyl 6-acetamidomethyl-2-oxo-2H-1-benzopyran-3-carboxylate (28a)}

Phenyl 6-aminomethyl-2-oxo-2H-1-benzopyran-3-carboxylate chloride salt (27a) ( $0.1 \mathrm{~g}, 0.3 \mathrm{mmol})$ and TEA $(0.06 \mathrm{ml}, 0.45 \mathrm{mmol})$ were suspended in acetic anhydride $(4 \mathrm{~mL}, 42.4 \mathrm{mmol})$. After $1 \mathrm{~h}$, distilled water $(50 \mathrm{~mL})$ was added and the suspension was stirred at room temperature for $1 \mathrm{~h}$. The resulting white precipitate was collected by filtration and washed with water. The crude product was then suspended in acetone for $15 \mathrm{~min}$, then collected by filtration: $\mathrm{mp}>260^{\circ} \mathrm{C}$; IR $3070(\mathrm{C}-\mathrm{H}$ arom $), 1774(\mathrm{C}=\mathrm{O}$ ester $), 1757(\mathrm{C}=\mathrm{O}$ lactone $), 1710(\mathrm{C}=\mathrm{O}$ amide), 1651, 1621, 1574, 1491, $1380 \mathrm{~cm}^{-1}$; ${ }^{1} \mathrm{H}$ NMR 1.91 (s, 3H, CH $H_{3}, 4.32\left(\mathrm{~s}, 2 \mathrm{H}, \mathrm{CH}_{2}\right), 7.29-7.35$ (m, 3H, 2'H, 4'-H, 6'-H), 7.48 (d, 1H, 8-H), 7.50-7.51 (m, 2H, 3'-H, 5'-H), 7.67 (d, 1H, 7-H), 7.80 (s, 1H, 5-H), 8.45 (s, $1 \mathrm{H}$, $\mathrm{NH}), 9.12(\mathrm{~s}, 1 \mathrm{H}, 4-\mathrm{H})$. Anal. $\mathrm{C}_{19} \mathrm{H}_{15} \mathrm{NO}_{5}(\mathrm{C}, \mathrm{H}, \mathrm{N})$.

\subsubsection{3-Fluorophenyl 6-acetamidomethyl-2-oxo-2H-1-benzopyran-3-carboxylate (28b)}

3-Fluorophenyl 6-aminomethyl-2-oxo-2H-1-benzopyran-3-carboxylate chloride salt (27b) $(0.1 \mathrm{~g}, 0.3 \mathrm{mmol})$ and TEA $(0.055 \mathrm{ml}, 0.43 \mathrm{mmol})$ were suspended in acetic anhydride $(4 \mathrm{~mL}, 42.4 \mathrm{mmol})$. After $1 \mathrm{~h}$, distilled water $(50 \mathrm{~mL})$ was added and the suspension was stirred at room temperature for $1 \mathrm{~h}$. The resulting white precipitate was collected by filtration and washed with water: $\mathrm{mp} 249-252^{\circ} \mathrm{C}$; IR $3070(\mathrm{C}-\mathrm{H}$ arom $), 1775(\mathrm{C}=\mathrm{O}$ ester $), 1759$ $(\mathrm{C}=\mathrm{O}$ lactone $), 1712(\mathrm{C}=\mathrm{O}$ amide $), 1649,1621,1574,1486,1377 \mathrm{~cm}^{-1} ;{ }^{1} \mathrm{HNMR} 1.90\left(\mathrm{~s}, 3 \mathrm{H}, \mathrm{CH}_{3}\right), 4.33(\mathrm{~s}, 2 \mathrm{H}$, $\mathrm{CH}_{2}$ ), 7.16-7.27 (m, 3H, 2'-H, 4'-H, 6'-H), 7.46 (d, 1H, 8-H), 7.52-7.55 (m, 1H, 5'-H), 7.68 (d, 1H, 7-H), 7.82 (s, $1 \mathrm{H}, 5-\mathrm{H}), 8.45(\mathrm{~s}, 1 \mathrm{H}, \mathrm{NH}), 9.09(\mathrm{~s}, 1 \mathrm{H}, 4-\mathrm{H})$. Anal. $\mathrm{C}_{19} \mathrm{H}_{14} \mathrm{NO}_{5} \mathrm{~F}(\mathrm{C}, \mathrm{H}, \mathrm{N})$.

\subsubsection{3-Chlorophenyl 6-acetamidomethyl-2-oxo-2H-1-benzopyran-3-carboxylate (28c)}

3-Chlorophenyl 6-aminomethyl-2-oxo-2H-1-benzopyran-3-carboxylate chloride salt (27c) (0.25 g, $0.68 \mathrm{mmol})$ and TEA $(0.103 \mathrm{~g}, 10 \mathrm{mmol})$ were suspended in acetic anhydride $(10 \mathrm{~mL}, 0.106 \mathrm{~mol})$. After $1 \mathrm{~h}$, distilled water $(50 \mathrm{~mL})$ was added and the suspension was stirred at room temperature for $1 \mathrm{~h}$. The resulting white precipitate was collected by filtration and washed with water: $\mathrm{mp} 241-242^{\circ} \mathrm{C}$; IR $3067(\mathrm{C}-\mathrm{H}$ arom $), 1777(\mathrm{C}=\mathrm{O}$ ester $), 1760$ $(\mathrm{C}=\mathrm{O}$ lactone $), 1714(\mathrm{C}=\mathrm{O}$ amide $), 1647,1621,1572,1472,1376 \mathrm{~cm}^{-1} ;{ }^{1} \mathrm{HNMR} 1.90(\mathrm{~s}, 3 \mathrm{H}, \mathrm{CH}), 4.33(\mathrm{~s}, 2 \mathrm{H}$, $\left.\mathrm{CH}_{2}\right), 7.29$ (d, 1H, 6'-H), 7.42 (d, 1H, 8-H), 7.45-7.48 (m, 2H, 2'-H, 4'-H), 7.53 (t, 1H, 5'-H), 7.68 (d, 1H, 7-H), $7.82(\mathrm{~s}, 1 \mathrm{H}, 5-\mathrm{H}), 8.46(\mathrm{~s}, 1 \mathrm{H}, \mathrm{NH}), 9.10(\mathrm{~s}, 1 \mathrm{H}, 4-\mathrm{H})$. Anal. $\mathrm{C}_{19} \mathrm{H}_{14} \mathrm{NO}_{5} \mathrm{Cl}(\mathrm{C}, \mathrm{H}, \mathrm{N})$.

\subsubsection{3-Bromophenyl 6-acetamidomethyl-2-oxo-2H-1-benzopyran-3-carboxylate (28d)}

3-Bromophenyl 6-aminomethyl-2-oxo-2H-1-benzopyran-3-carboxylate chloride salt (27d) (0.5 g, $1.2 \mathrm{mmol})$ and TEA $(0.18 \mathrm{~g}, 1.8 \mathrm{mmol})$ were suspended in acetic anhydride $(15 \mathrm{~mL}, 159 \mathrm{mmol})$ and heated under reflux for $1 \mathrm{~h}$. After cooling, distilled water $(50 \mathrm{~mL})$ was added and the suspension was stirred at room temperature for $1 \mathrm{~h}$. The resulting brown pasty precipitate was collected by filtration and washed with water. The crude product was suspended in ethyl acetate and the resulting precipitate was collected by filtration, washed with ethyl acetate and dried: $\mathrm{mp} 233.5-235^{\circ} \mathrm{C}$; IR 3064 (C-H arom), 1776 ( $\mathrm{C}=\mathrm{O}$ ester), 1761 ( $\mathrm{C}=\mathrm{O}$ lactone), 1715 ( $\mathrm{C}=\mathrm{O}$ amide), 1646, 1620, 1572, 1470, $1376 \mathrm{~cm}^{-1}$; ${ }^{1} \mathrm{H}$ NMR $1.90\left(\mathrm{~s}, 3 \mathrm{H}, \mathrm{CH}_{3}\right), 4.33(\mathrm{~s}, 2 \mathrm{H}, \mathrm{CH}), 7.33$ (d, 1H, 6'- $\left.\mathrm{H}\right), 7.45-7.48(\mathrm{~m}$, 2H, 5'-H, 8-H), 7.55 (d, 1H, 4'-H), 7.60 (s, 1H, 2'-H), 7.67 (d, 1H, 7-H), 7.82 (s, 1H, 5-H), 8.45 (s, 1H, NH), 9.10 $(\mathrm{s}, 1 \mathrm{H}, 4-\mathrm{H})$. Anal. $\mathrm{C}_{19} \mathrm{H}_{14} \mathrm{NO}_{5} \mathrm{Br}(\mathrm{C}, \mathrm{H}, \mathrm{N})$.

\subsubsection{3-Iodophenyl 6-acetamidomethyl-2-oxo-2H-1-benzopyran-3-carboxylate (28e)}

3-Iodophenyl 6-aminomethyl-2-oxo-2H-1-benzopyran-3-carboxylate chloride salt (27e) (0.25 g, $0.55 \mathrm{mmol})$ and 
TEA $(0.08 \mathrm{~g}, 0.8 \mathrm{mmol})$ were suspended in acetic anhydride $(10 \mathrm{~mL}, 106 \mathrm{mmol})$. After $30 \mathrm{~min}$, the mixture was gently heated for another $30 \mathrm{~min}$. Then, distilled water $(50 \mathrm{~mL})$ was added and the suspension was stirred at room temperature for $1 \mathrm{~h}$. The resulting white precipitate was collected by filtration and washed with water: $\mathrm{mp}$ 223-224 ${ }^{\circ} \mathrm{C}$; IR 3056 (C-H arom), 1763 (C=O ester and lactone), 1718 (C=O amide), 1650, 1622, 1573, 1466, $1376 \mathrm{~cm}^{-1}$; ${ }^{1} \mathrm{H}$ NMR $1.90\left(\mathrm{~s}, 3 \mathrm{H}, \mathrm{CH}_{3}\right), 4.32$ (s, 2H, $\left.\mathrm{CH}_{2}\right), 7.28-7.35$ (m, 2H, 5'-H, 6'-H), 7.46 (d, 1H, 8-H), 7.667.73 (m, 3H, 2'-H, 4'-H, 7-H), 7.81 (s, 1H, 5-H), 8.46 (s, 1H, NH), 9.08 (s, 1H, 4-H). Anal. $\mathrm{C}_{19} \mathrm{H}_{14} \mathrm{NO}_{5} \mathrm{I}(\mathrm{C}, \mathrm{H}$, N).

\subsection{Biological assays}

\subsubsection{Chemoinvasion assay with HT 1080 fibrosarcoma cells}

5.4.1.1. Cell culture. Human fibrosarcoma HT 1080 cells were maintained in Dulbecco's Modified Eagle's Medium (DMEM) supplemented with 10\% (v/v) fetal calf serum (FCS), penicillin — streptomycin (100 UI/mL$100 \mu \mathrm{g} / \mathrm{mL}), 2 \mathrm{mM}$ glutamine and $10 \mathrm{mM}$ HEPES buffer at $37^{\circ} \mathrm{C}$ in a humid atmosphere $\left(5 \% \mathrm{CO}_{2}\right.$ and $\left.95 \% \mathrm{O}_{2}\right)$.

5.4.1.2. Coating of culture wells with type IV collagen. Twenty four-well plates (Falcon, Becton-Dickinson, USA) and $6.5 \mathrm{~mm}$ polycarbonate filters $(8 \mu \mathrm{m}$ pore size) of Transwell cell culture chamber inserts (Costar, Netherlands) were coated with type IV collagen purified from human placenta diluted at $200 \mu \mathrm{g} / \mathrm{mL}$ in phosphate-buffered saline (PBS): $3 \mu \mathrm{L}$, then $5 \mu \mathrm{L}$, then $10 \mu \mathrm{L}$ of this solution were added successively to the centre of filters. Collagen solution was then diluted to $100 \mu \mathrm{g} / \mathrm{mL}$ and two more additions were done. After each addition, coats were left to air-dry in a laminar flow hood under UV light. Thus, the final amount of collagen was about $\pm 24 \mu \mathrm{g}$. Before use, coated plates and inserts were washed twice with sterile water and incubated for at least $1 \mathrm{~h}$ in serum-free DMEM at $37^{\circ} \mathrm{C}$.

5.4.1.3. Preparation of HT 1080 cell suspension. HT 1080 cells cultured in T-75 flasks (Nunc, Costar, Netherlands) at 70-80\% confluence were collected, after trypsin-ethylene-diaminetetracetic acid treatment, in 20 mL DMEM supplemented with $10 \%$ FCS and centrifuged at $1000 \mathrm{tr} / \mathrm{min}$ for $5 \mathrm{~min}$. Cell suspension was placed for at least $30 \mathrm{~min}$ in a humid atmosphere at $37^{\circ} \mathrm{C}$. Cells were then resuspended in $20 \mathrm{~mL}$ serum-free DMEM, centrifuged and finally diluted in the same medium supplemented with $1 \%$ bovine serum albumin (BSA, fraction V, Sigma, USA) to a density of $6 \times 10^{5}$ cells $/ \mathrm{mL}$. Viability and count of cells were assessed in Thomas chamber after trypan blue staining.

5.4.1.4. Invasion assay. The inhibitory potency of new synthetic coumarins (at $0.1,1$ and $10 \mu \mathrm{M}$ ) on HT 1080 fibrosarcoma cell invasion and migration was assayed using a 'Boyden chamber' test. For chemoinvasion assays, type IV collagen membranes (see above) were used. Lower wells of chambers were filled with $600 \mu \mathrm{L}$ DMEM supplemented with $20 \% \mathrm{FCS}$ (acting as chemoattractant), $1 \%$ BSA and $6 \mu \mathrm{L}$ of an inhibitor solution $\left(10^{-5}, 10^{-4}\right.$ and $10^{-3} \mathrm{M}$ in DMEM supplemented with $10 \%$ dimethylsulphoxyde). Filters were recovered with $100 \mu \mathrm{L}$ of cell suspension ( 6 x 10 cells), $200 \mu \mathrm{L}$ DMEM supplemented with $0.1 \%$ BSA and $3 \mu \mathrm{L}$ of inhibitor solution. Chambers were subsequently incubated for $48 \mathrm{~h}$ (in order to maintain a chemotactic gradient), media from both lower and upper wells were renewed after $24 \mathrm{~h}$ in a humid atmosphere at $37^{\circ} \mathrm{C}$. After incubation, cells at the bottom of filters were fixed in $4 \%$ paraformaldehyde for $15 \mathrm{~min}$ at $4{ }^{\circ} \mathrm{C}$, permeabilised for $10 \mathrm{~min}$ in absolute methanol at $-20^{\circ} \mathrm{C}$ and stained with Giemsa (4\% in sterile water) (Fluka 48900) for $15 \mathrm{~min}$. The exceeding dye was removed by washing with water and cells on the upper surface of filters were eliminated by scrapping with a cotton swab. Cells having reached the lower surface of the filters were visually counted using a light microscope (Vanox AH3, Olympus, Hamburg, Germany). Each essay was performed in triplicate $(n=3)$. Results were expressed as percentage $( \pm$ s.d.) of the migration of control cells.

\section{Acknowledgements}

This study was supported by grants from the National Fund for Scientific Research (F.N.R.S., Belgium) from which P. de Tullio is Research Associate. The technical assistance of Y. Abrassart and F. Olivier is gratefully acknowledged.

\section{References}

[1] H. Zhong, J.P. Bowen, Curr. Med. Chem. 13 (2006) 849-862.

[2] T. Cascone, T. Troiani, M.P. Morelli, C. Gridelli, F. Ciardiello, Curr. Opin. Oncol. 18 (2006) 151-155.

[3] E. Cabebe, H. Wakelee, Drugs Today (Barc) 42 (2006) 387-398.

[4] C. Verhoef, J.H. de Wilt, H.M. Verheul, Curr. Pharm. Des. 12 (2006) 2623-2630.

[5] V. Roy, E.A. Perez, Semin. Oncol. 33 (2006) S3-S8.

[6] G.K. Dy, A.A. Adjei, A.A. Clin, Lung Cancer 7 (2006) S145-S149. 
Published in: European Journal of Medicinal Chemistry (2008), vol. 43, iss. 12, pp. 2735-2750.

Status : Postprint (Author's version)

[7] L. Balasubramanian, A.M. Evens, Curr. Opin. Oncol. 18 (2006) 354-359.

[8] C. Nieder, N. Wiedenmann, N. Andratschke, M. Molls, Cancer Treat. Rev. 32 (2006) 348-364.

[9] R.J. Motzer, S. Hoosen, C.L. Bello, J.G. Christensen, Expert Opin. Invest. Drugs 15 (2006) 553-561.

[10] I. Kempen, D. Papapostolou, N. Thierry, L. Pochet, S. Counerotte, B. Masereel, J.M. Foidart, M. Reboud-Ravaux, A. Noel, B. Pirotte, Br. J. Cancer 18 (2003) 1111-1118.

[11] T. Okamoto, T. Kobayashi, S. Yoshida, Curr. Med. Chem. Anticancer Agents 5 (2005) 47-51.

[12] I. Kostova, Curr. Med. Chem. Anticancer Agents 5 (2005) 29-46.

[13] A. Lacy, R. O'Kennedy, Curr. Pharm. Des. 10 (2004) 3797-3811.

[14] G. Finn, B. Creaven, D. Egan, Eur. J. Pharmacol. 481 (2003) 159-167.

[15] S. Han, V. Zhou, S. Pan, Y. Liu, M. Hornsby, D. McMullan, H.E. Klock, J. Haugen, S.A. Lesley, N. Gray, J. Caldwell, X.J. Gu, Bioorg. Med. Chem. Lett. 15 (2005) 5467-5473.

[16] N.S. Reddy, K. Gumireddy, M.R. Mallireddigari, S.C. Cosenza, P. Venkatapuram, S.C. Bell, E.P. Reddy, M.V. Reddy, Bioorg. Med. Chem. 13 (2005) 3141-3147.

[17] J. Vukanovic, A. Passaniti, T. Hirata, R. Traystman, B. Hartley-Asp, J.T. Isaacs, Cancer Res. 53 (1993) $1833-1837$.

[18] I.B. Joseph, J. Vukanovic, J.T. Isaacs, Cancer Res. 56 (1996) 3404- 3408.

[19] J. Shi, Z. Xiao, M.A. Ihnat, C. Kamat, B. Pandit, Z. Hu, P.K. Li, Bioorg. Med. Chem. Lett. 13 (2003) 1187-1189.

[20] K.B. Dasari, T.J. Srikrishnan, Chem. Crystallogr. 32 (2002) 499-504.

[21] L. Pochet, C. Doucet, G. Dive, J. Wouters, B. Masereel, M. Reboud-Ravaux, B. Pirotte, Bioorg. Med. Chem. 8 (2000) 1489-1501.

[22] J. Wouters, M. Huygens, L. Pochet, B. Pirotte, F. Durant, B. Masereel, Bioorg. Med. Chem. Lett. 12 (2002) $1109-1112$.

[23] L. Pochet, C. Doucet, M. Schynts, N. Thierry, N. Boggetto, B. Pirotte, K.Y. Jiang, B. Masereel, P. de Tullio, J. Delarge, M.J. ReboudRavaux, Med. Chem. 39 (1996) 2579-2585.

[24] A.R. Daniewski, W. Liu, M. Okabe, Org. Proc. Res. Develop. 8 (2004) 411-414. 